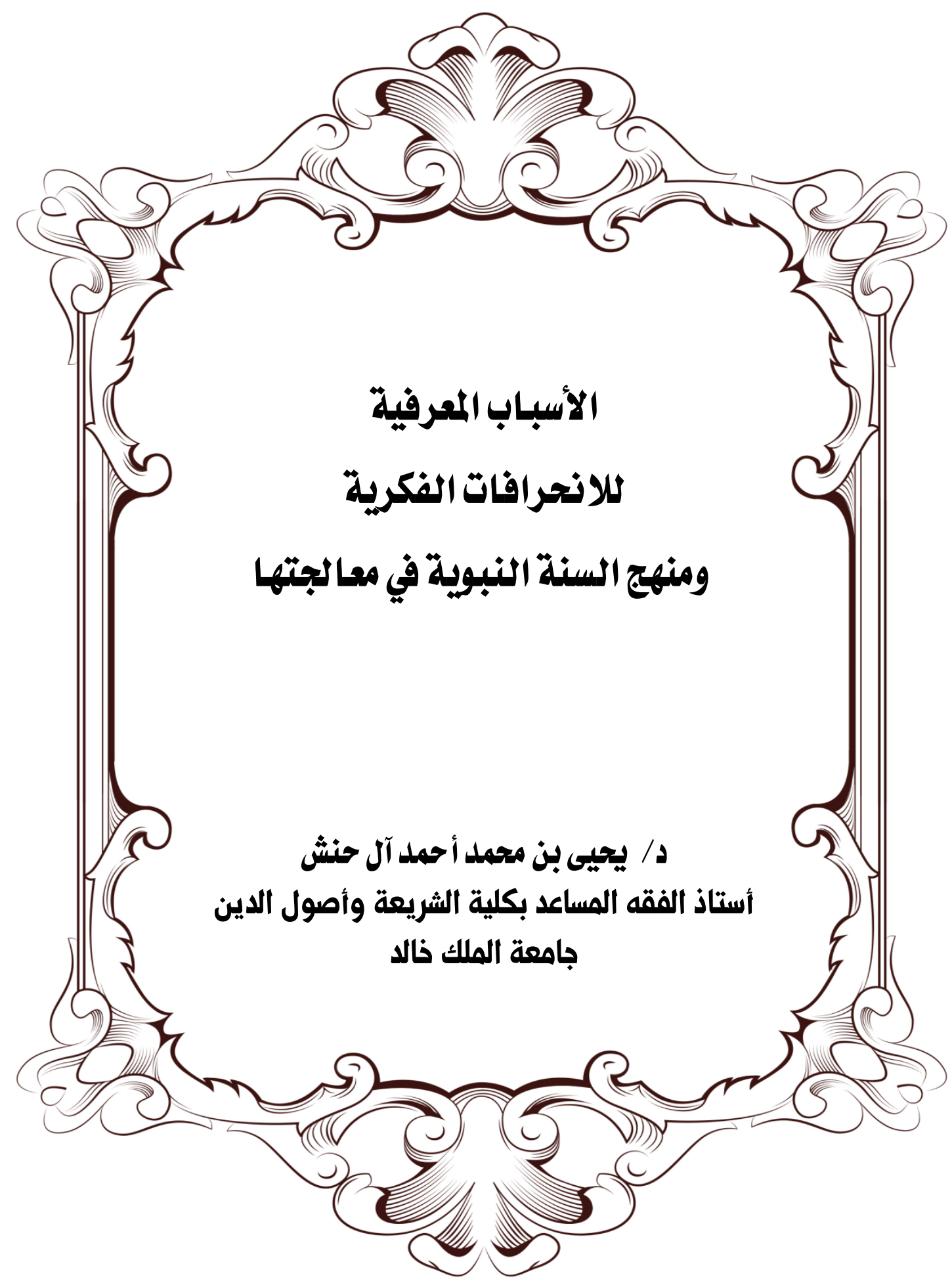


مجلة كلية الدراسات الإسلامية والعربية للبنات بدمنهور العدد الخامس الجزء السادس •r+rم

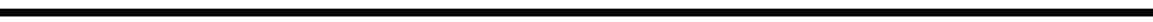




\section{(شكر وتقدير)}

قال صلى الله عليه وسلم: " من لا يشكر الناس لا يشكر الله " فأحمد الله سبحانه وتعالى أن أعانتي على إتمام هذا البحث. والثكر موصول إلى عمادة البحث العلمي في جامعة الملتك خالد على دعمها لهذا البحث من خلال البرنامج البحثي العام تحث رقم:(191 )

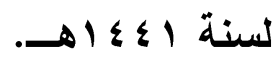


مجلة كلية الدراسات الإسلامية والعربية للبنات بدمنهور العدد الخامس الجزء السادس •r.rم

الأسباب المعرفية للانحر افات الفكرية ومنهج السنة النبوية في معالجتها

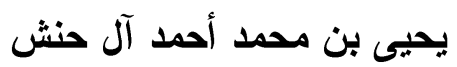

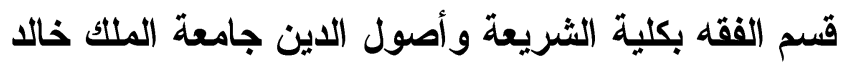

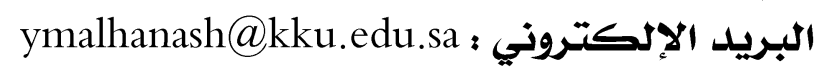

الملخص:

يتحدث هذا البحث عن الأسباب المعرفية المؤثرة في الانحراف الفكري تحت عنوان: (الأسباب المعرفية للانحر افات الفكرية ومنهج السنة النبوية في معالجتها).

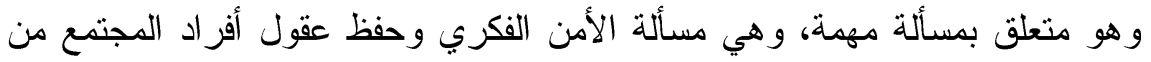

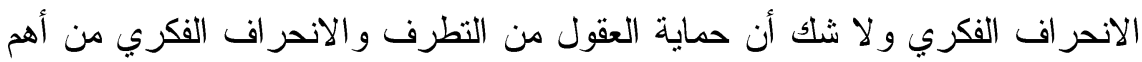

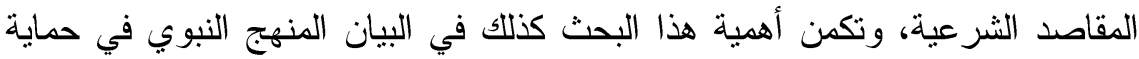

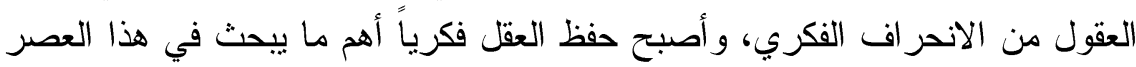

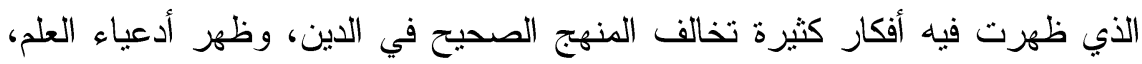

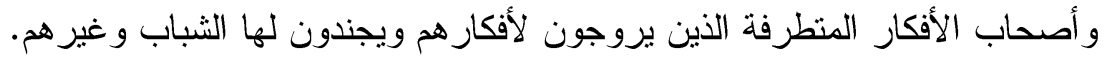

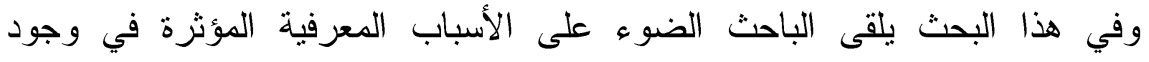

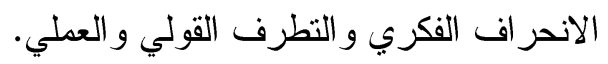
ويتعرض البحث لبيان المنهج النبوي في مواجهة النطرف ولفئ والانحراف المتحقق من الأسباب المعرفية. وقد استعمل الباحث المنهج التحليلي فيما يتعلق بالأسباب المعرفية الذاتية والخارجية

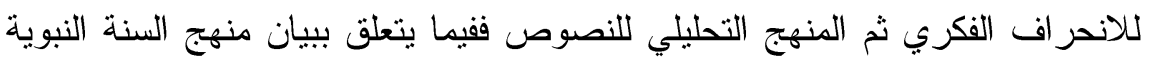
في معالجة الانحر اف الفكري. وتوصل الباحث إلى عدة نتائج لعل أهمها: أن هنالك الكثير الوسائل المعرفية المؤدية

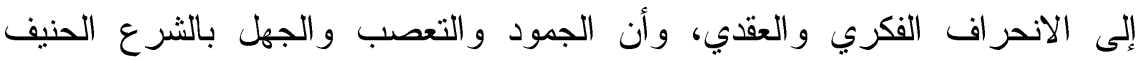

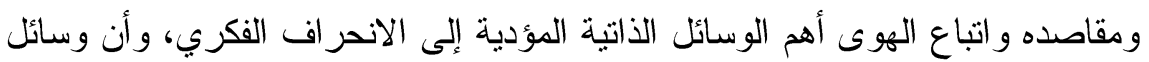

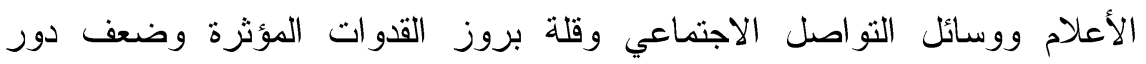

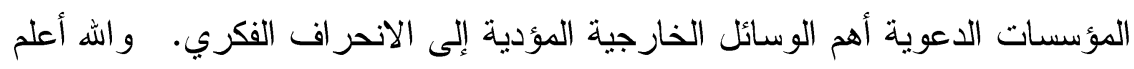

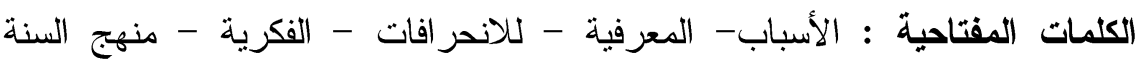
النبوية 
الأسباب المعرفية للانحرافات الفكرية ومنهج السنة النبوية في معالجتها

the cognitive causes of intellectual deviations and the methodology of the Prophet's Sunnah in dealing with them

Yahya bin Mohammed Ahmed Al Hanash

Department of Jurisprudence, College of Sharia and Fundamentals of Religion, King Khalid University

Email: ymalhanash@kku.edu.sa

Abstract :

This research talks about the cognitive causes affecting intellectual deviation under the title: (the cognitive causes of intellectual deviations and the methodology of the Prophet's Sunnah in dealing with them).

It is related to an important issue, which is the issue of intellectual security and preserving the minds of members of society from intellectual deviation, and there is no doubt that protecting minds from extremism and intellectual deviation is one of the most important legitimate aims, and the importance of this research also lies in the statement of the prophetic approach in protecting minds from intellectual deviation, and the preservation of the mind has become intellectual The most important thing is discussed in this era in which many ideas emerged that contradict the correct approach in religion, and the pretenders of knowledge and extremist ideas who promoted their ideas and recruited youth and others for them appeared.

In this research, the researcher sheds light on the cognitive causes affecting the existence of intellectual deviation and extremism in verbal and practical.

The research presents an explanation of the prophetic approach in the face of extremism and the deviation that is realized from the cognitive causes. 
The researcher used the analytical method with regard to the subjective and external cognitive causes of intellectual deviation, and then the analytical method for the texts, with regard to the statement of the Sunnah approach in dealing with intellectual deviation.

The researcher reached several results, perhaps the most important of which are: that there are many cognitive means leading to intellectual and doctrinal deviation, and that stagnation, intolerance, and ignorance of the righteous law and its purposes and following whims are the most important subjective means leading to intellectual deviation, and that the media and social media outlets and the lack of prominence of influential role models and the weak role of advocacy institutions The most important external means leading to intellectual deviation. God knows

Key words: The Cognitive Causes Of Deviations - The Intellectual - The Approach Of The Prophet's Sunnah 


\section{الأسباب المعرفية للانحرافات الفكرية ومنهج السنة النبوية في معالجتها}

\section{بسم الله الرحمن الرحيم}

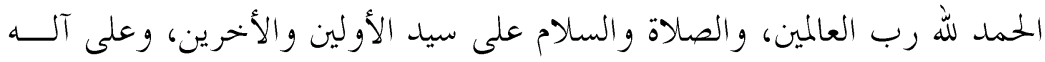

وأصحابه، ومن سار على فجهم واتبع ملتهم إلى يوم الدين.

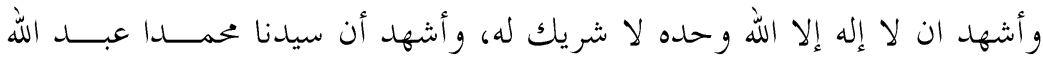

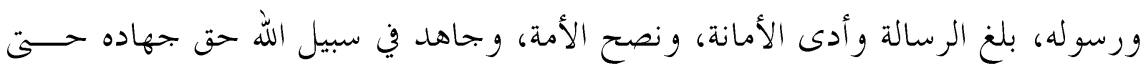

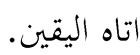

\section{وبعد}

فإن قضية الانحراف الفكري من أخطر القضايا التي تواجه المختمعات الإسلامية، بل

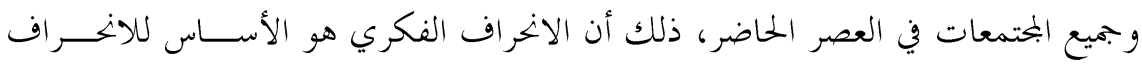
السلوكي، وما ينتج عنه من غلو وتشدد، أو تساهل وتسيب.

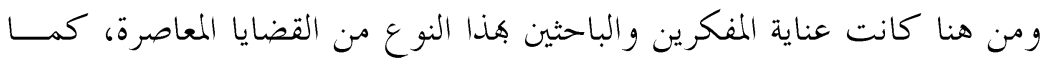

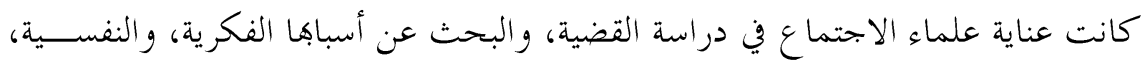

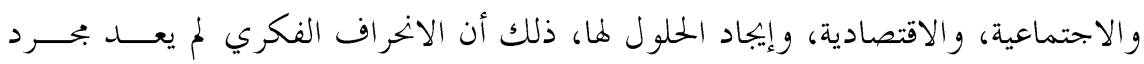

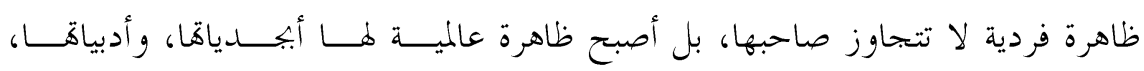

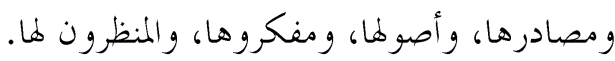

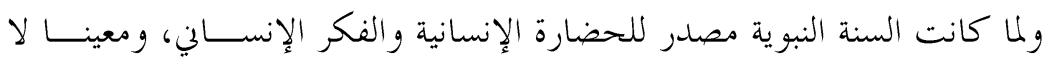

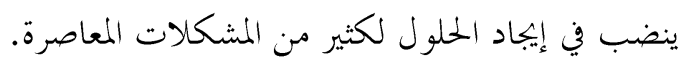

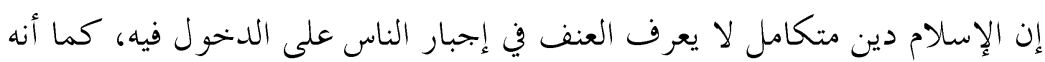

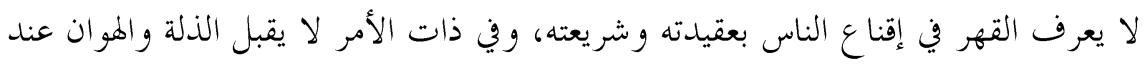

$$
\text { الاعتداء على مقدساته، أو انتهاك حرماته. }
$$

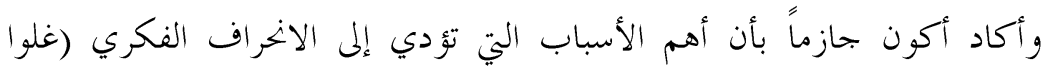

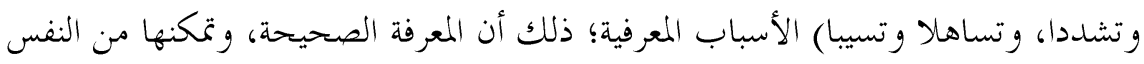
الإنسانية عصمة لها من الانخر اف بكافة مستو ياته، و وبكافة بحالاتها

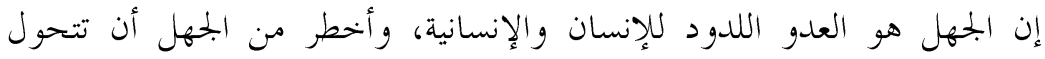

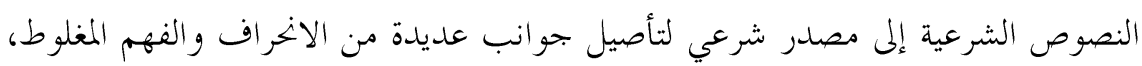

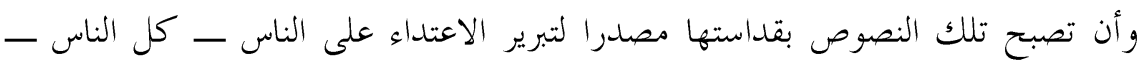
وترويعهم، واستحلال دمائهم وأمو الهم وأعراضهم. 
مشكلة البحث:

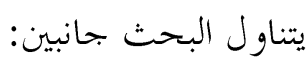

الجانب الأول فيما يتعلق بالبحث في الأسباب المعرفية للانخر اف الفكري.

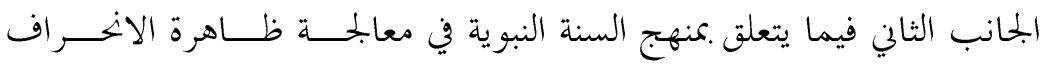
الفكري.

و كلا الجانبين يمثل مشكلة من المشاكل التي يجب تناولها بالدراسة والتأصيل.

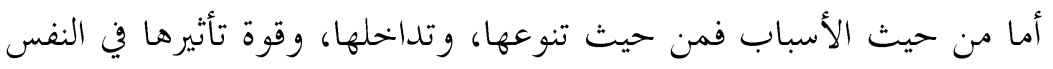
الإنسانية إيجابا وسلبا، وما يتبع ذلك من إيباد الحلول لمن لما.

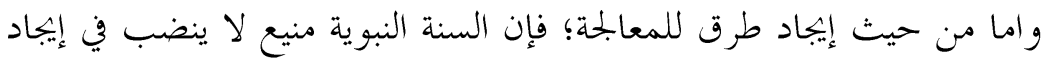

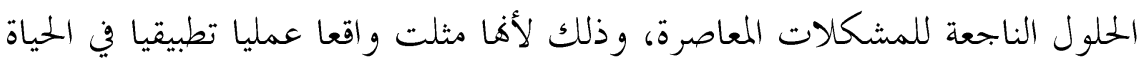

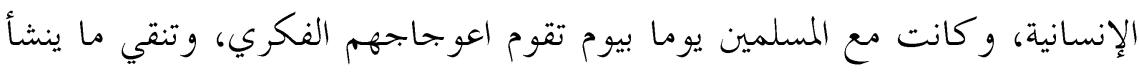

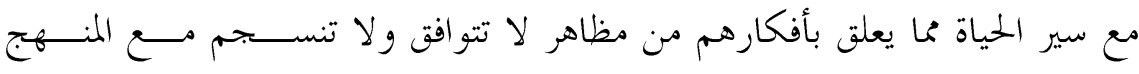
الإسلامي السليم. ومن هنا كانت السنة النبوية بكل ما اشتملت عليه من توجيهات ربانية، أو أو

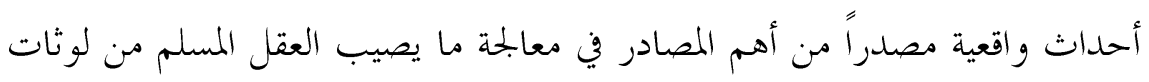
الانحر افات الفكرية.

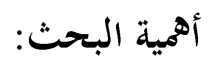
تظهر أهمية البحث من خحلال جانبين: الجحانب الأول: في البحث عن أسباب الانخر اف الفكري فيما يتعلق بالنواحي

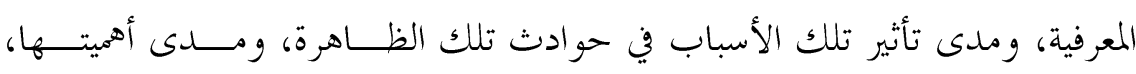
وو اقعيتها. الجحانب الثالي: في البحث حول منهج السنة النبوية في معالجة الأسباب المعرفية

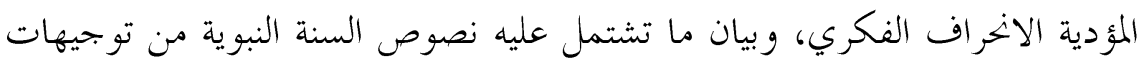

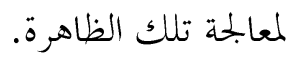




\section{أهداف البحث:}

$$
\text { r- بيان المقصود بالانحر اف الفكري. }
$$

r- بيان عناية القر آن الكريم والسنة النبوية بمو اجهة الانحر اف الفريان الفكري.

ع - بيان الأسباب الذاتية للانخر اف الفكري فيما يتعلق بالجانب المعرفي.

0- بيان الأسباب الخارجية للانحر اف الفكري فيما يتعلق بالجانب المعر في.

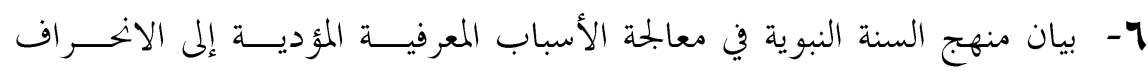

$$
\text { تساؤلات البحث: الفكري. }
$$

ا - - ما المقصود بالانحر اف الفكري؟

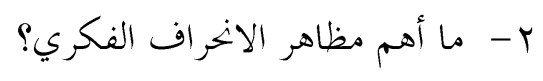

ب- هل كان للقر آن الكريم والسنة النبوية عناية بمواجهة الانحر اف الفريك الفكري؟

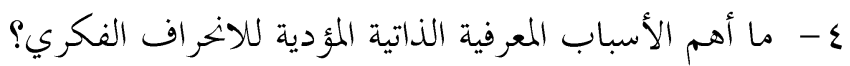

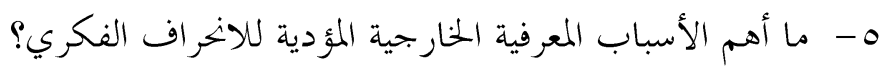

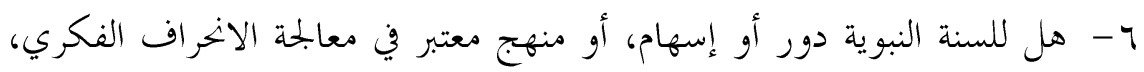

$$
\text { منهج البحث: ذاتيا، وخارجيا؟ }
$$

اعتمدت على المنهج التحليلي فيما يتعلق بالأسباب المعرفية الذاتية والخارجية

$$
\text { للانحر اف الفكري. }
$$

ثم المنهج التحليلي للنصوص ففيما يتعلق ببيان منهج السنة النبوية في معالجة

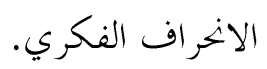


مجلة كلية الدراسات الإسلامية والعربية للبنات بدمنهور العدد الخامس الجزء السادس •r.rم

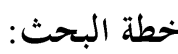

انتمل البحث على مقدمة وتمهيد، وثلاثة مباحث، وخاتمة.

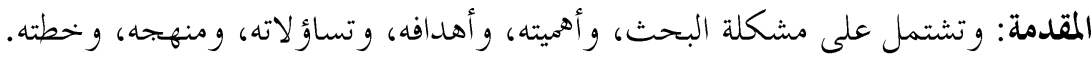

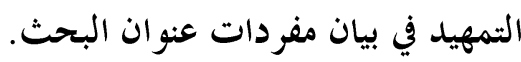

المطلب الأول: بيان حقيقة الأسباب المعرفية.

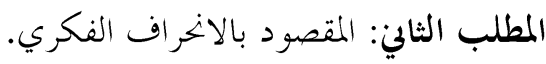

المطلب الثالث: مظاهر الانخر اف الفكري.

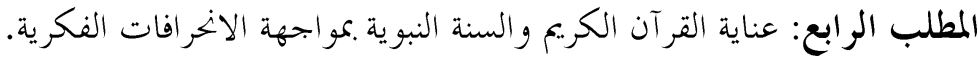

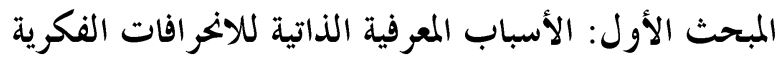

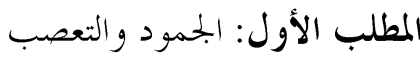

المطلب الثابي: الجهل المل بالدين ومقاصده.

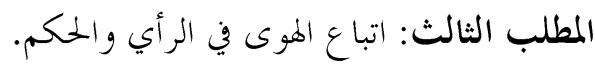

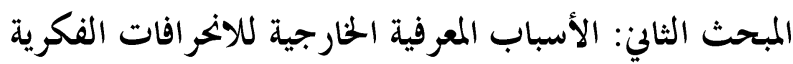

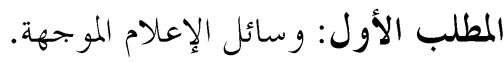

المطلب الثالي: وسائل التواصل الاجتماعي. الإعلام الموحة.

المطلب الثالث: ضعف دور المؤسسات الدعب المعية.

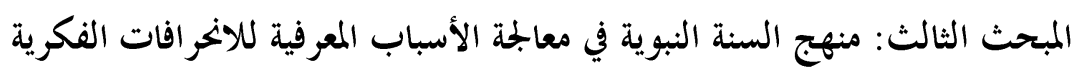

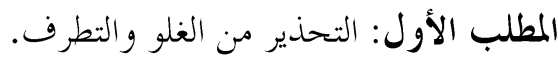

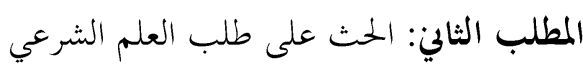

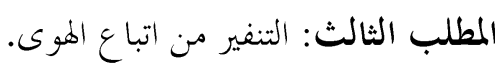

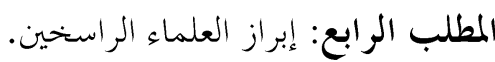

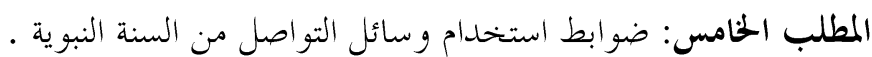

المطلب السادس: التعريف بمذاهب أهل الغلو والتنفير منها.

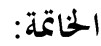

وتشتمل على:

1- أهم النتائج والتو صيات.

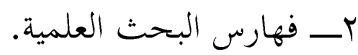




\section{الأسباب المعرفية للانحرافات الفكرية ومنهج السنة النبوية في معالجتها}

\section{التمهيد}

في بيان مفردات عنوان البحث.

لما كان هذا البحث منتظماً في الكلام عن الأمن الفكري وأثره في تحقيق

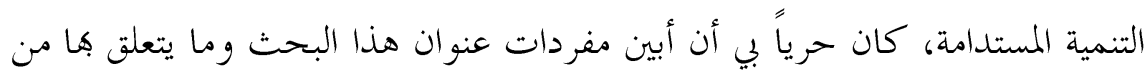
مسائل وذلك من خلال المطالب الآتية: -

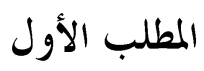

\section{بيان حقيقة الأسباب المعرفية.}

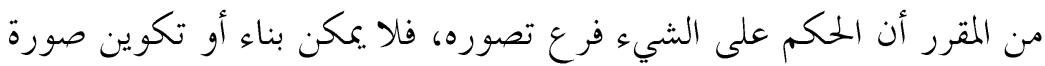

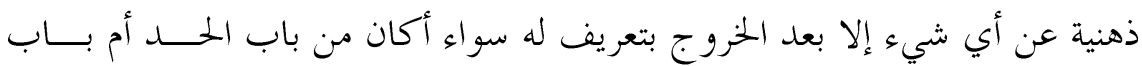

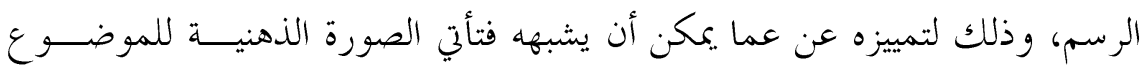

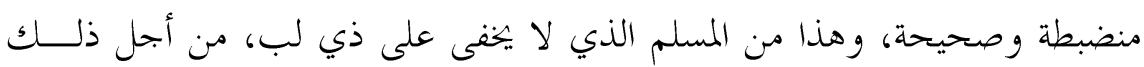

$$
\text { سوف يدور الكالام في هذا الفروع الآتية: - }
$$

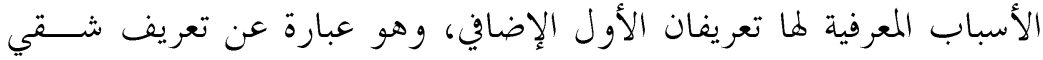
الكلمة المضاف والمضاف إليه، وهذا يعرف علمياً بالتعريف بالإضافة.

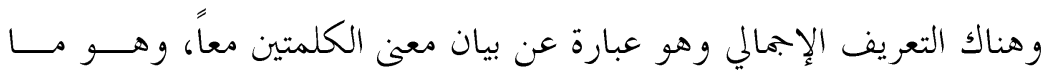

$$
\text { يعرف بالتعريف اللقبي }
$$

وسوف أقوم بتعريف الأسباب المعرفية بالتعريفين تتميما للفائدة. 


\section{الأول: التعريف الإضافي.}

وهو يقوم على تعريف المضاف والمضاف إليه (الأسباب) و (المعرفية).

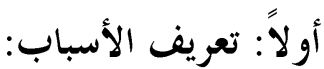

الأسباب لغة همع سبب، والسبب: هو كل ما يتوصل به إلى مقصود ما (1)؛

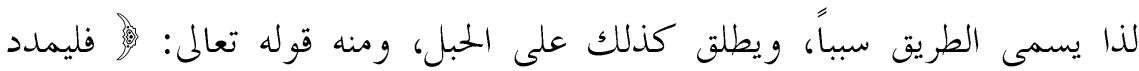

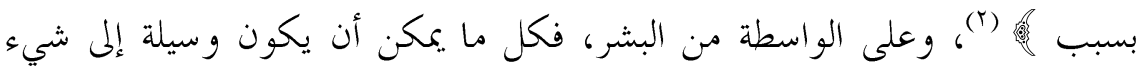

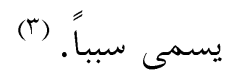

وفي اصطلاح الأصوليين: هو الذي يَلزم من وجوده الوجود، ومن عدمه

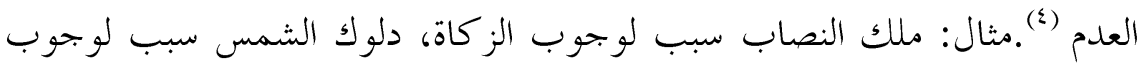

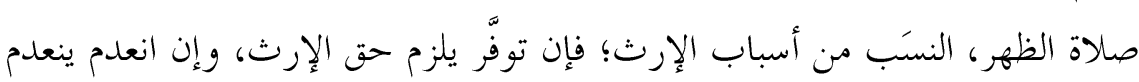

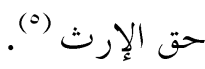
وعلى ذلك فالأسباب هي الأمور الموصلة إلى غيرها ومرتبطة هـا ما جابي

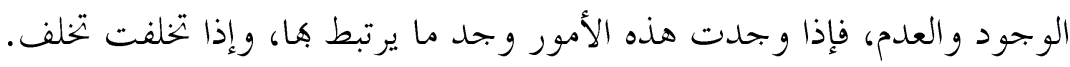

(1) انظر: الإحكام في أصول الأحكام المؤلف: أبو الحسن سيد الدين علي بن أبي علي بن محمد بن سالم الثعلبي الآمدي

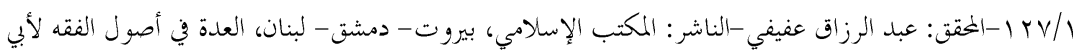

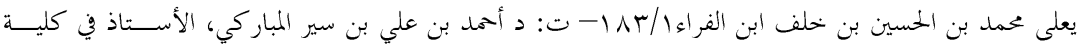

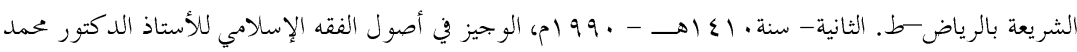

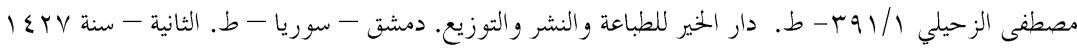

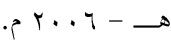
(r) من الآية هم: من سورة الكهف.

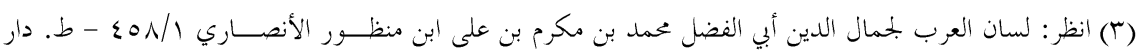

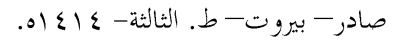

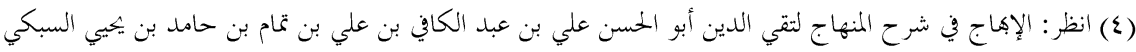

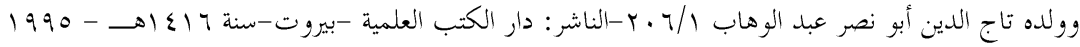

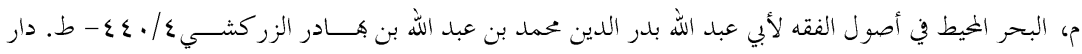

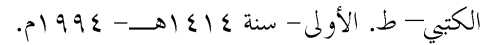

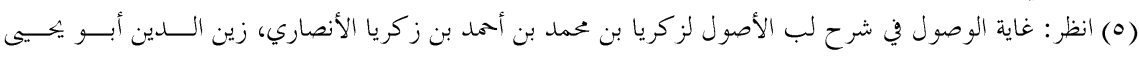

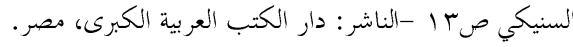


المعرفة مأخوذة من الفعل عرف يعرف معرفة، وعرَّف الشَّيَ؛: حلَّد معناه

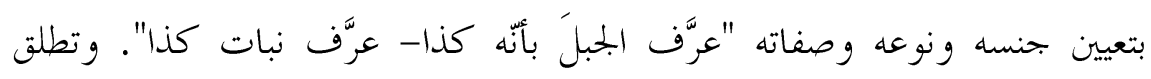

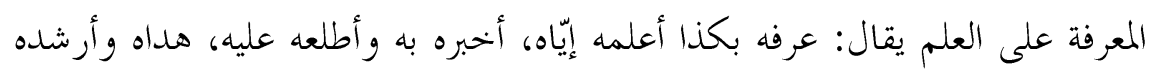
إليه (1)

واصطلاحاً: هي نتاج تفسير الإنسان وتعليله للظواهر المختلفة، وعادة ما

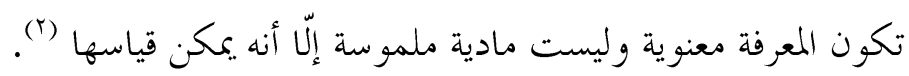

$$
\text { الثالي: التعريف اللقبي. }
$$

هي عبارة عن بحمو ع الخبرات، والمعلومات و المهارات التي تشكل قاعدة بمكن

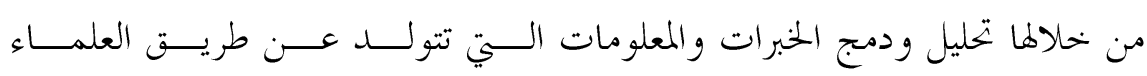
و الباحثين (")

واصطلاحاً: بمكن تعريفها بأها: عبارة عن بمموعة الإدراكات التي يكصلها

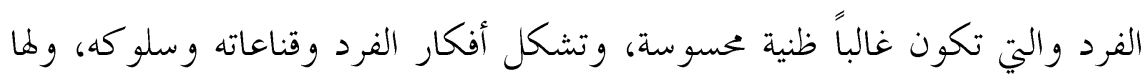

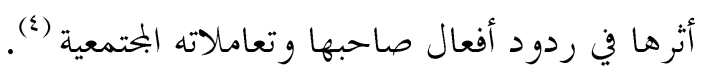

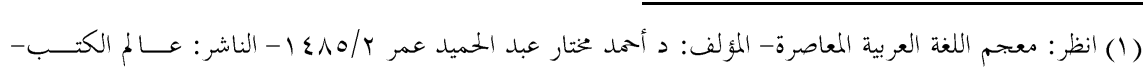

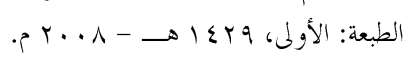

(r) تعريف العلم والمعرفة- كتابة غادة الحلايقة https://mawdoo3.com/\%D8\%AA\%D8\%B9\%D8\%B1\%D9\%8A\%D9\%81_\%D8 \%A7\%D9\%84\%D8\%B9\%D9\%84\%D9\%85_\%D9\%88\%D8\%A7\%D9\%84\%

D9\%85\%D8\%B9\%D8\%B1\%D9\%81\%D8\%A9 (r) تعريف العلم والمعرفة- كتابة غادة الحلايقة https://mawdoo3.com/\%D8\%AA\%D8\%B9\%D8\%B1\%D9\%8A\%D9\%81_\%D8 \%A7\%D9\%84\%D8\%B9\%D9\%84\%D9\%85_\%D9\%88\%D8\%A7\%D9\%84\%

D9\%85\%D8\%B9\%D8\%B1\%D9\%81\%D8\%A9 
مجلة كلية الدراسات الإسلامية والعربية للبنات بدمنهور العدد الخامس الجزء السادس •r.rم

\section{الفرق بين العلم والمعرفة.}

\section{يتلخص الفرق بين العلم والمعرفة فيما يأيّ:}

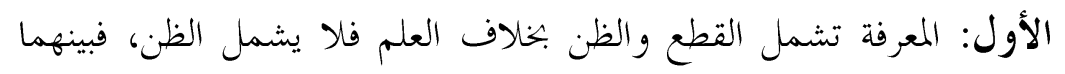

عمو و وخصوص مطلق يجتمعان في القطع وينفرد الأعم وهو المعرفة بالظن.

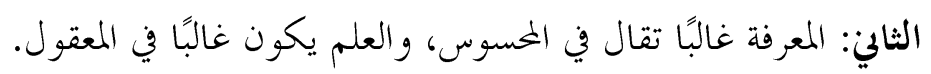

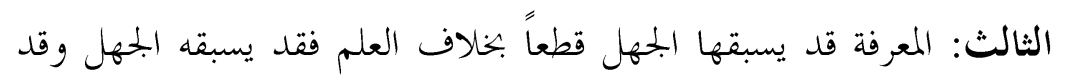

يسبقه؛ لذا لم يجزز أن يطلق وصف المعرفة على الله تعالى (1).

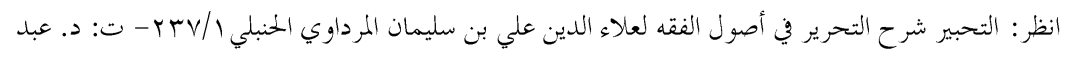

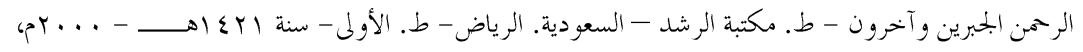

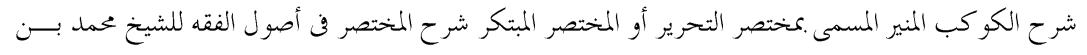

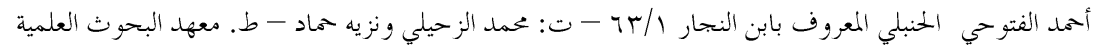

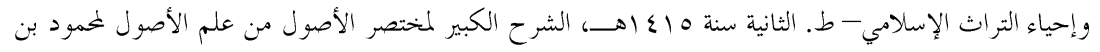

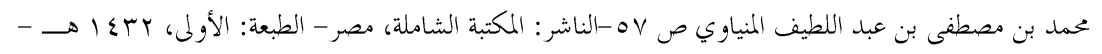




\section{المطلب الثاني \\ المقصود بالانخر اف الفكري.}

كما سبق الكلام عن بيان مقصود الأسباب المعرفية فمن متممات الفائدة بيان المقصود بالانحراف الفكري؛ لأنه بيت القصيد في هذا الموضوع ومحور الدراسة فيه؛ لذا سوف يدور الحديث في هذا المطلب في فرعين: الفرع الأول

\section{بيان المقصود بالانخر اف بالمعنى الإضافي}

أولاً: معنى الانخر اف.

الانخراف أصله الميل والعدول عن الشيء (1). يقال الخرف عنه ينحرف

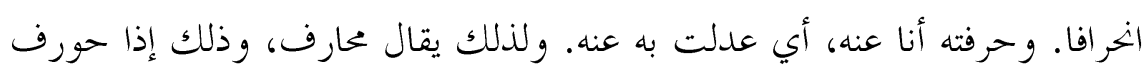

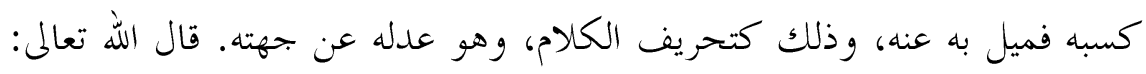

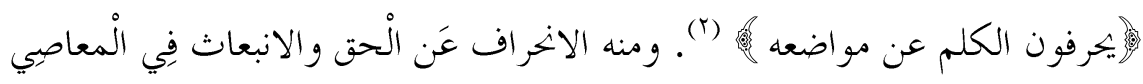

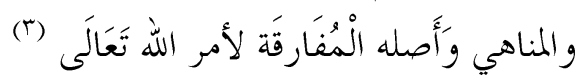

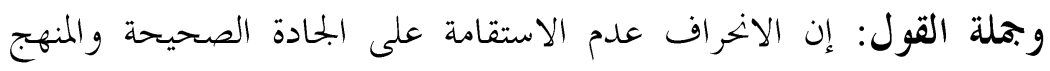

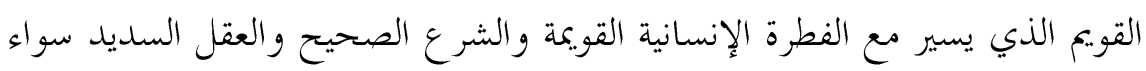
أكان في جانب الدين أم في الدنيا فكل ميل وبعد عن هذه الأمور يسمى الخر الفاً.

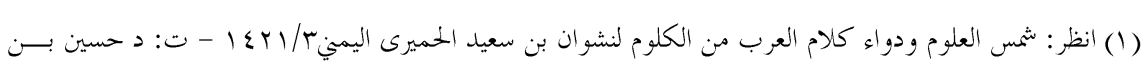

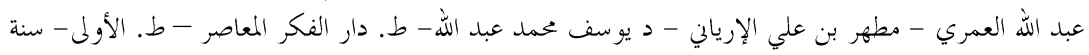

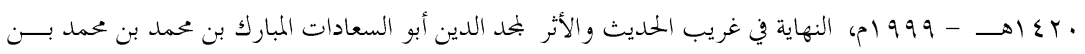

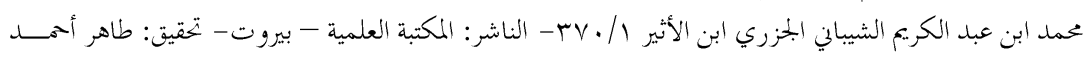

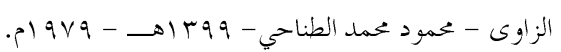

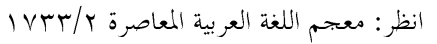

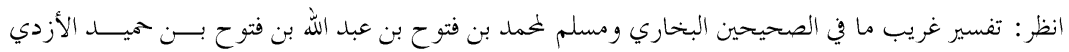

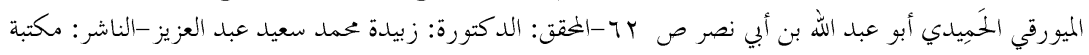

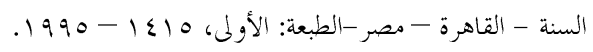




\section{ثانياً: تعريف الفكر.}

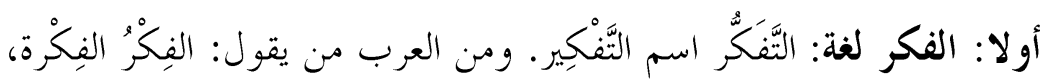

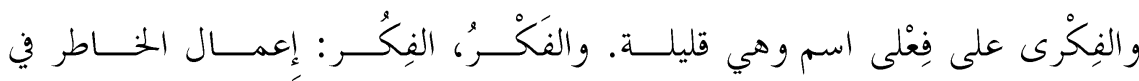

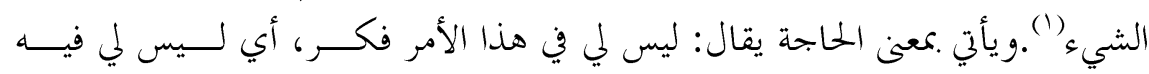
حابة) (ז) ويأليّ بعمنى: تردد القلب. يقال تفكر إذا ردد قلبه معتبرا. ورجل فكير: كثير

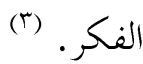

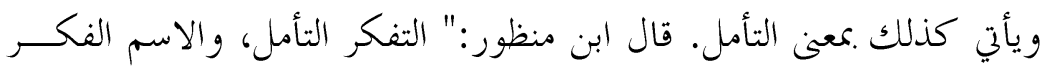

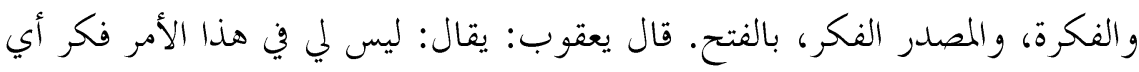

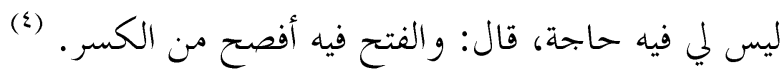

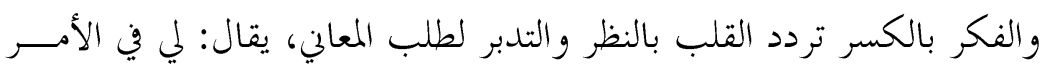

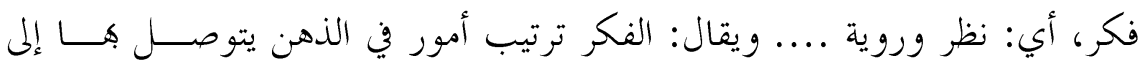

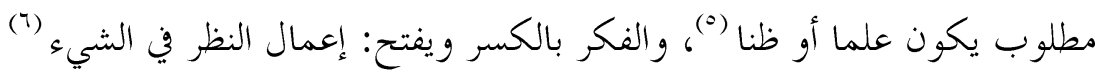

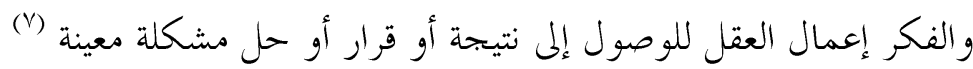

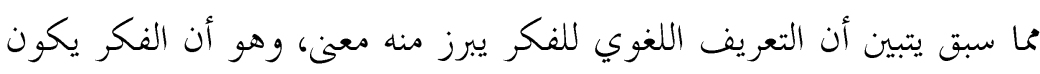

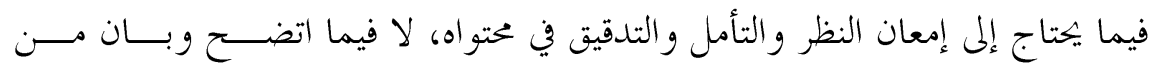
الأمور.

$$
\begin{aligned}
& \text { 70/0. (1) لسان العرب لابن منظور }
\end{aligned}
$$

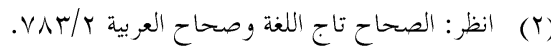

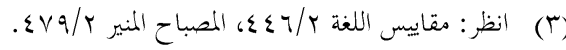

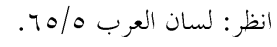

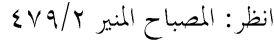

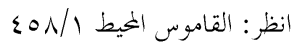

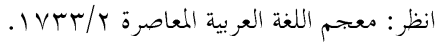


الأسباب المعرفية للانحرافات الفكرية ومنهج السنة النبوية في معالجتها

ثانياً: الفكر اصطلاحا:

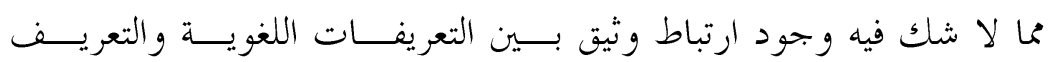

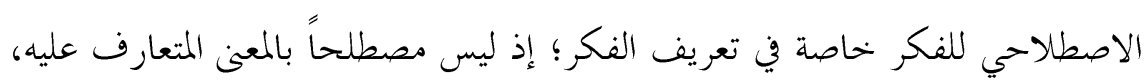

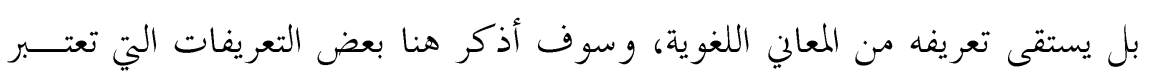
اصطلاحية، وإن كانت راجعة إلى المعنى اللغوي: -

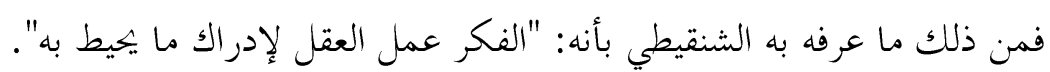

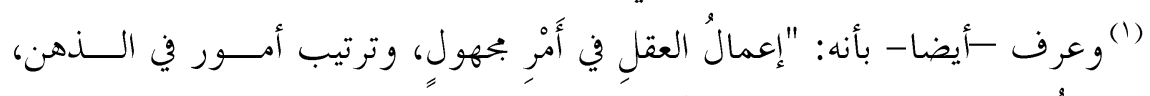

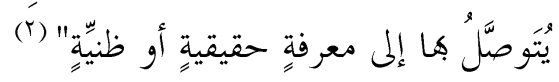

وعرفه -أيضاً - اسم لعملية تردد القوى العاقلة المفكرة في الإنســان ســــــاء

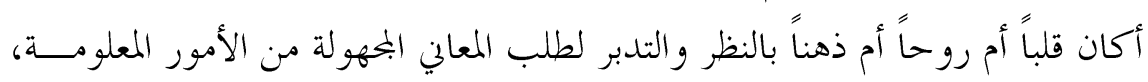

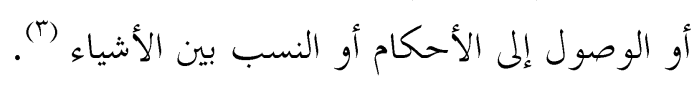

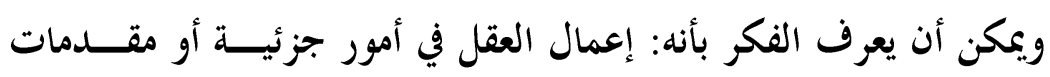

عقلية للوصول إلى حكم كلي أو نتيجة عامة تكون أساساً لمنطلق عملي.

$$
\text { شرح التعريف: التوصئ }
$$

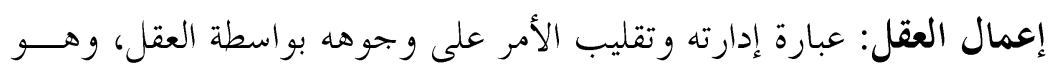

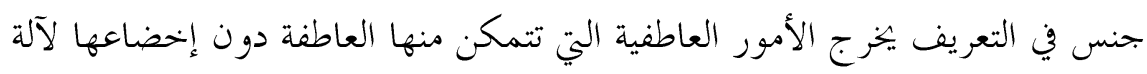

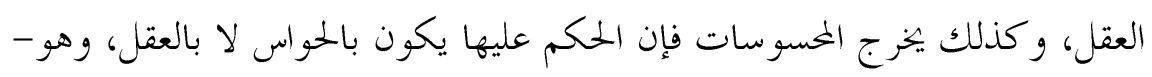

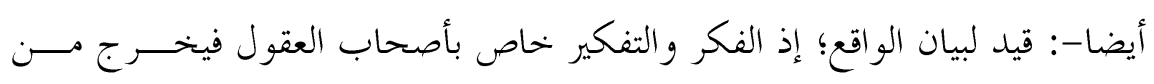

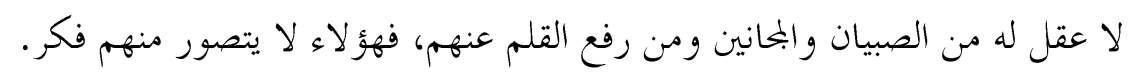

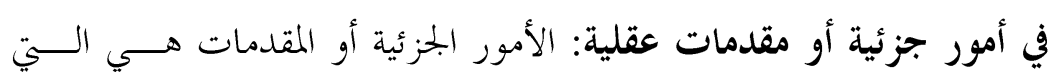

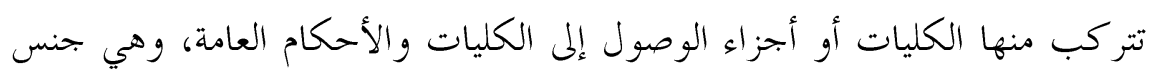

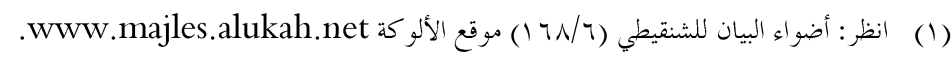

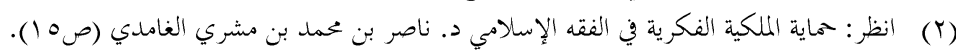

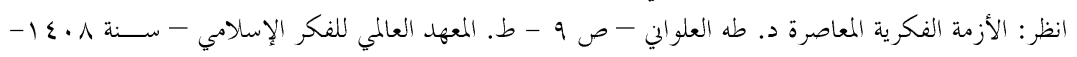

. 1911 
مجلة كلية الدراسات الإسلامية والعربية للبنات بدمنهور العدد الخامس الجزء السادس •r.rم

في التعريف لإخراج النتائج العلمية أو القواعد الكلية المستخلصة من مقدمات ونتائج

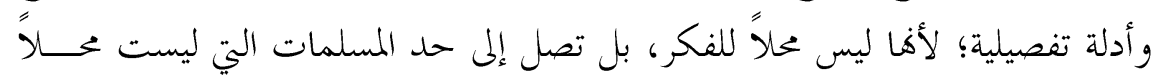

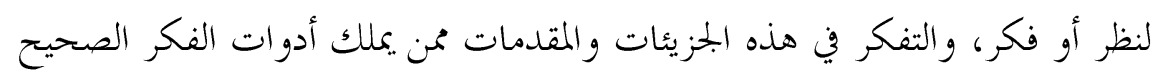

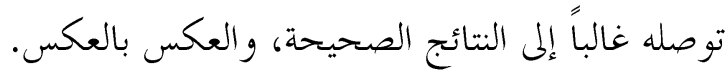

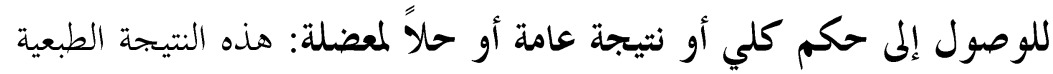

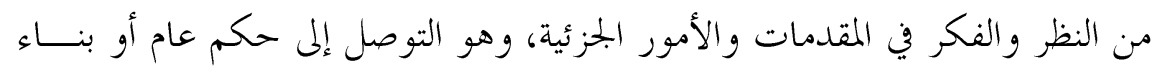

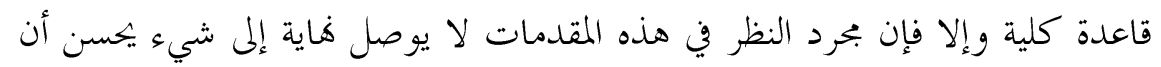

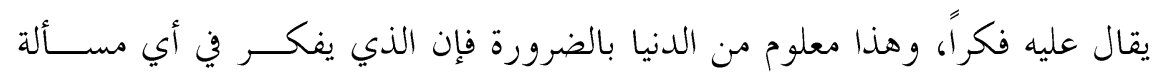

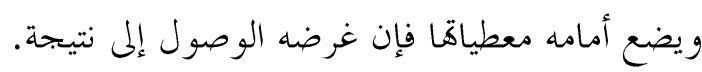

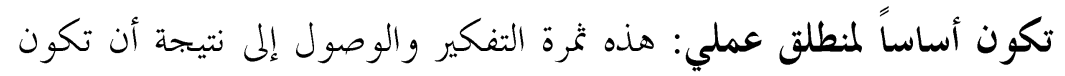

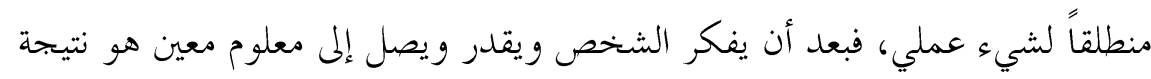

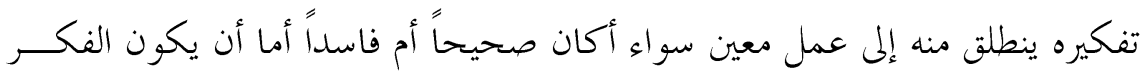
بلا أثر في الواقع، فإنه يعد ضرباً من العبث. وبملة القول تتلخص فيما يلي: -

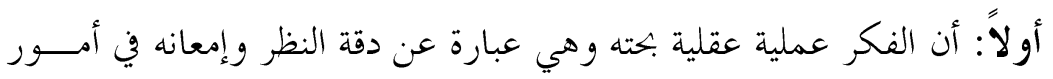
تؤدي ذاية إلى معرفة ما كان بمهولاً.

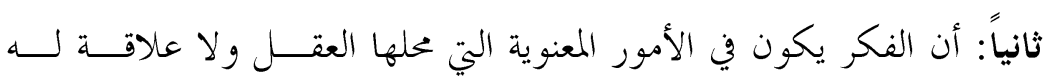

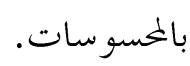
ثالثاً: أن الفكر لا يكون في المسلمات، بل يطلق على ما يحتاج إلى إطالة نظر و إمعان عقل. 


\section{الأسباب المعرفية للانحرافات الفكرية ومنهج السنة النبوية في معالجتها}

$$
\text { الفرع الثر الثياني }
$$

\section{تعريف الانحر اف الفكري بالمعنى اللببي.}

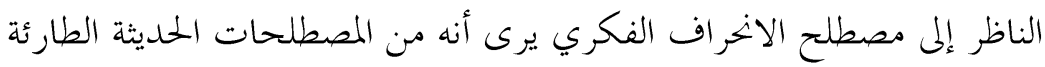

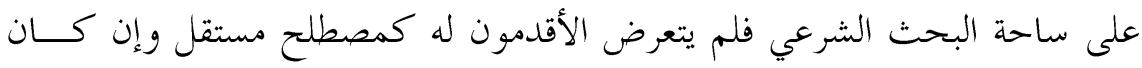

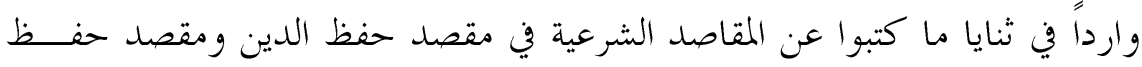

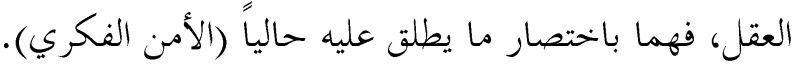

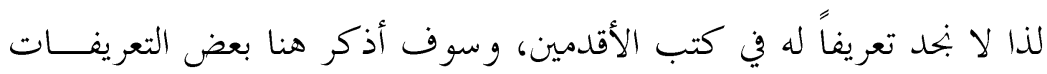

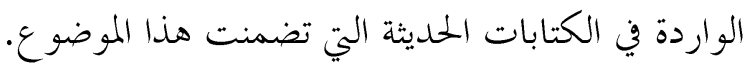

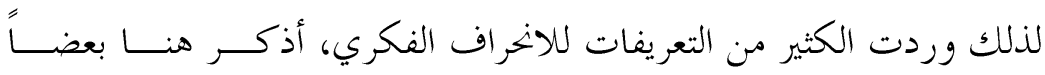

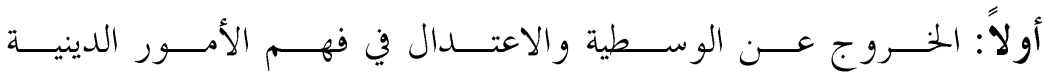

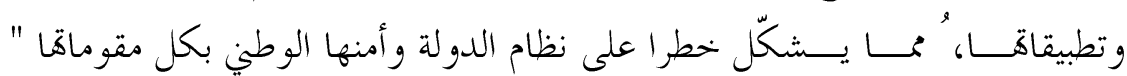

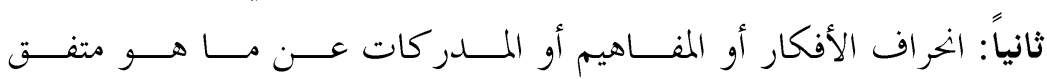

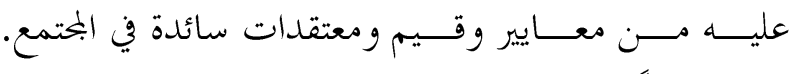

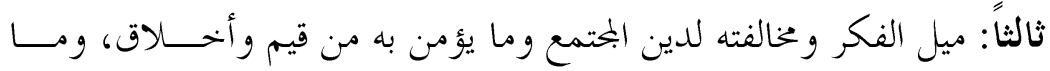

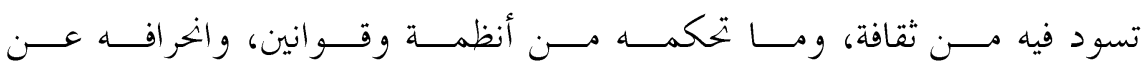

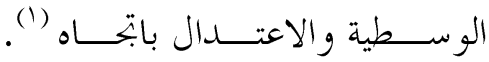

ويمكن تعريف الانحراف بأنه: هو عبارة عن عدم سلامة العقل من الأفكار

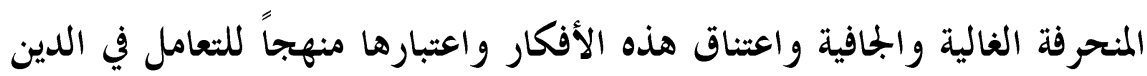

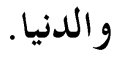

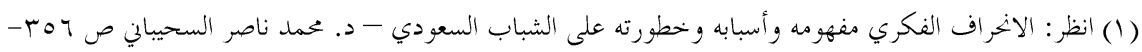

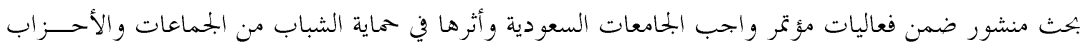

والانخراف- جامعة الإمام محمد بن سعود الإسلامية. 
مجلة كلية الدراسات الإسلامية والعربية للبنات بدمنهور العدد الخامس الجزء السادس •r.rم

\section{المطلب الثالث \\ مظاهر الانخر اف الفكري}

للانحر اف الفكري مظاهر متعددة بخملها فيما يلي: -

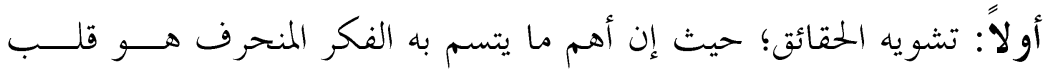

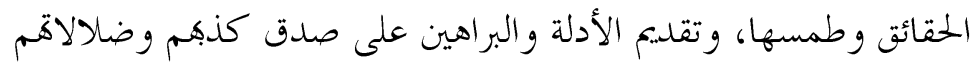

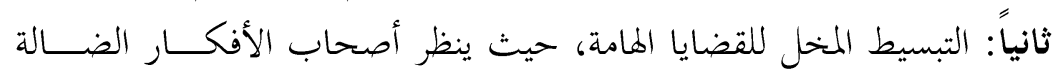

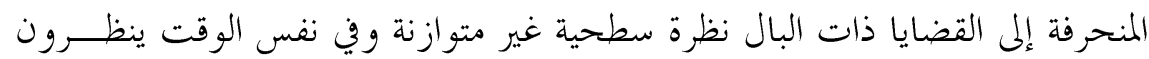

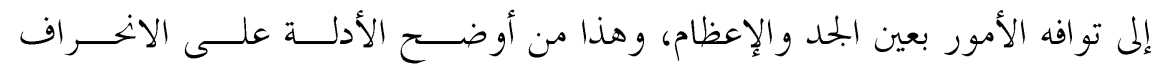

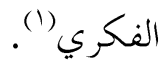

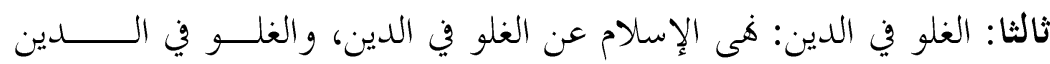

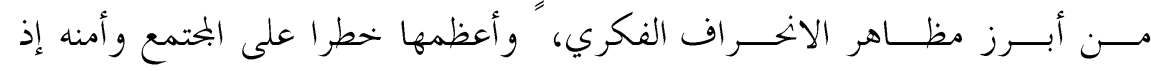

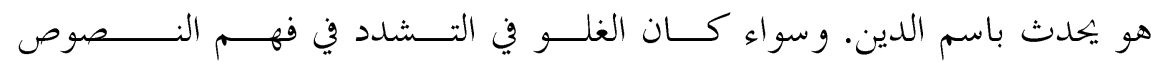

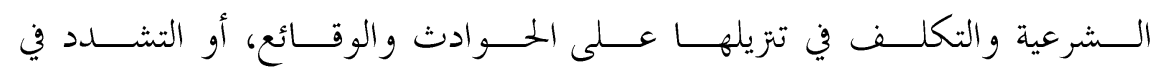

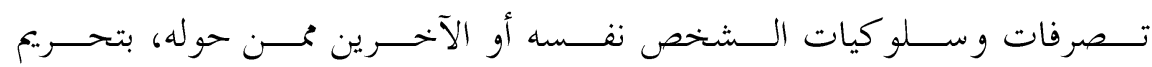

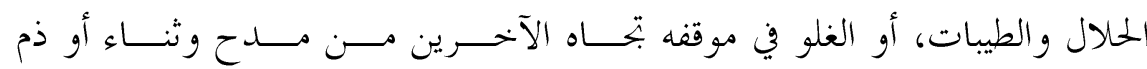

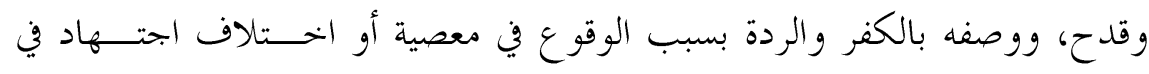
مسألة.

رابعاً: التكفير: يعد من أخطر مظاهر الاخرراف الفكري هو تكفــير الغــير

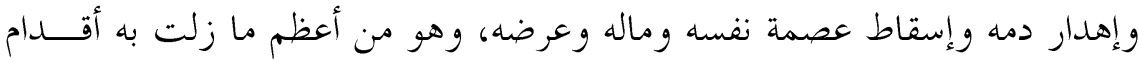
أصحاب الفكر الضال (r) خامساً: التعصب: الضعال كان التعصب ولا يزال من أهم الآفات التي تسيطر علــى التصى

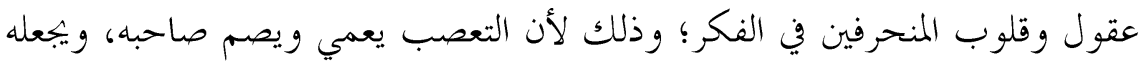

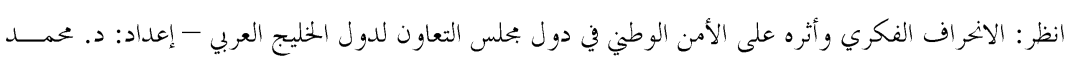




\section{الأسباب المعرفية للانحرافات الفكرية ومنهج السنة النبوية في معالجتها}

مغلق القلب والفهم، ولا يرى إلا رأي من يتعصب لهم حتى وإن كانت مخالفاً للنص

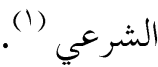

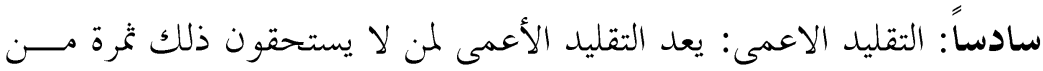

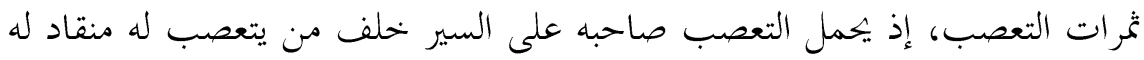

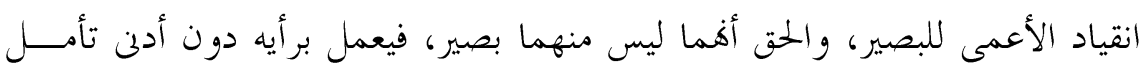

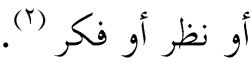

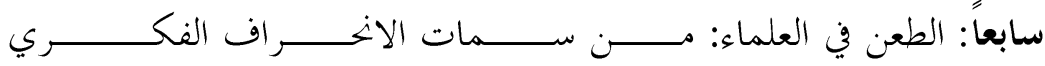

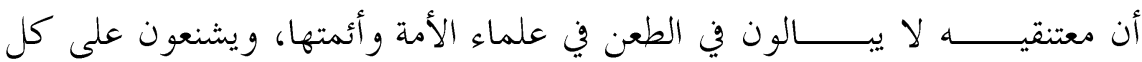

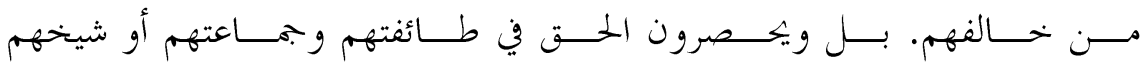
وزعيمهم (r)

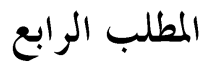

\section{عناية القر آن الكريم والسنة النبوية بمواجهة الانحر افات الفكرية}

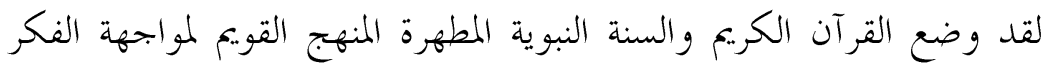

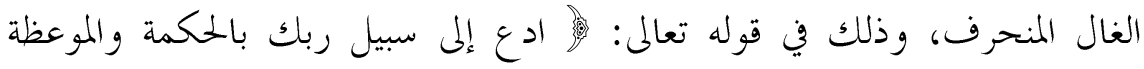

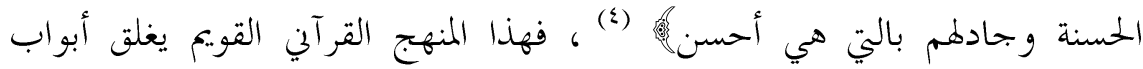

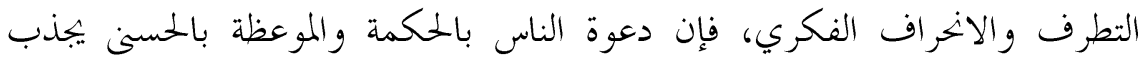
القلوب، ويمنع تفلت الناس، ويجمع ولا يفرق، حتى من كان في قلبه شيء فإن

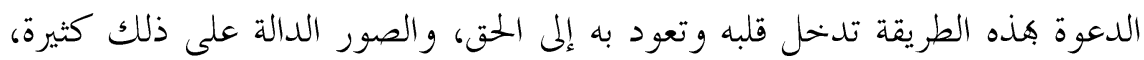

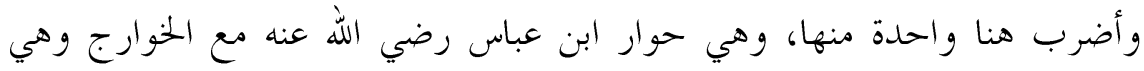

(1) انظر : من مظاهر الانخراف الفكري - عبد الله علي الشهراني .https://www.alwatan.com.sa/article/267050 (r) انظر: المصدر السابق.

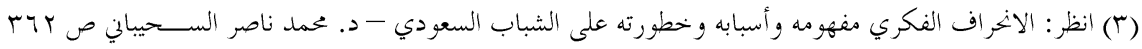
وما بعدها. (ع) من الآية هب ا: النحل. 
تعتبر من أشهر المناظرات التي وقعت في التاريخ الإسلامي (1)، وقد قام ابن عباس

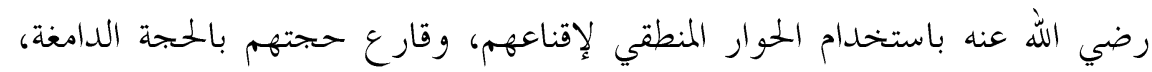

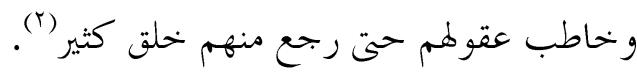

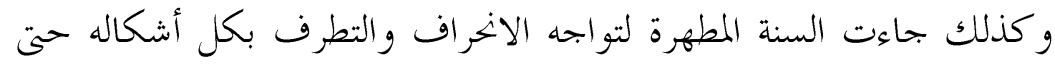

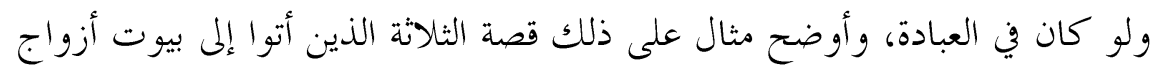

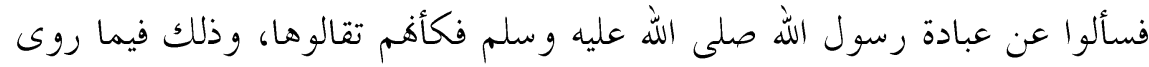

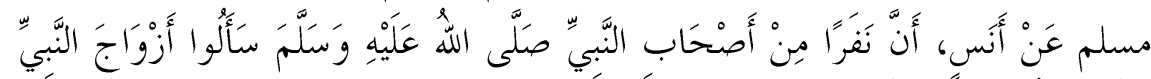

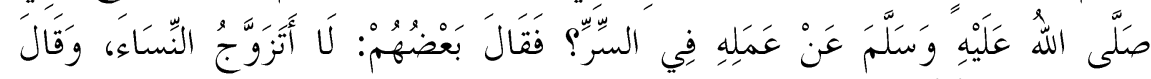

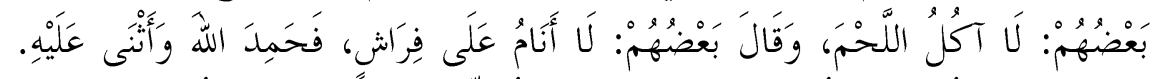

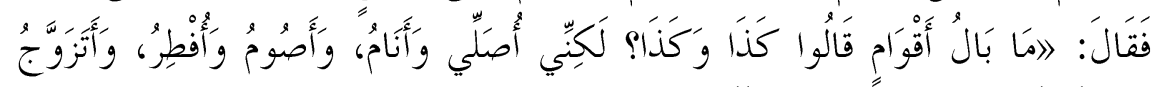

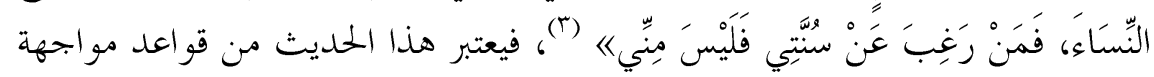

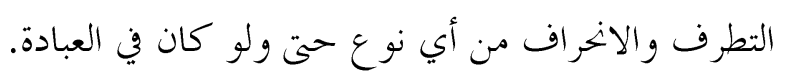

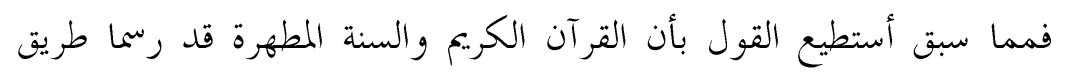

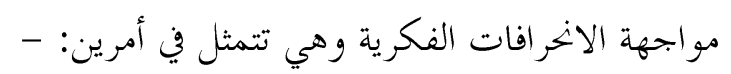

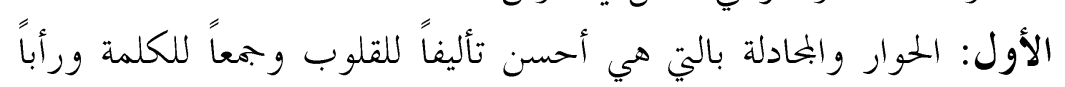

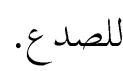
الثاني: مواجهة الانحراف بالتعليم والأخذ على يد المنحرفين لردهم إلى جادة الصواب.

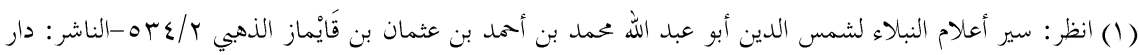

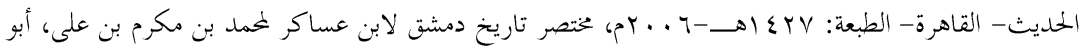

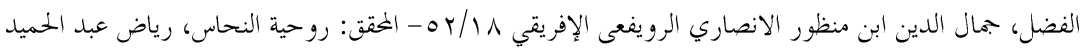

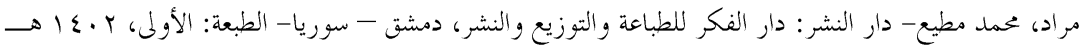
> $912 \varepsilon-$

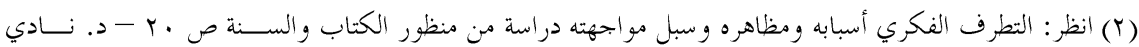

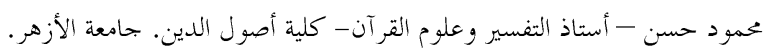

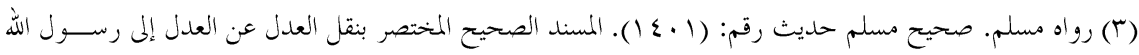

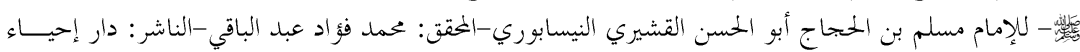
التراث العربي - بيروت. 
الأسباب المعرفية للانحرافات الفكرية ومنهج السنة النبوية في معالجتها

\section{المبحث الأول}

\section{الأسباب المعرفية الذاتية للانحر افات الفكرية}

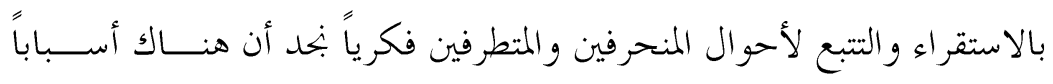

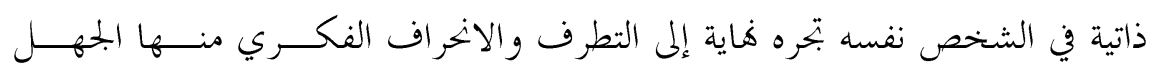

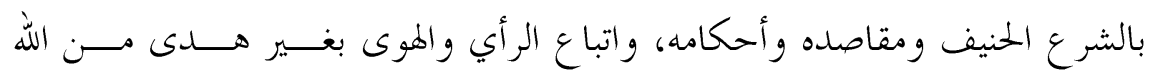

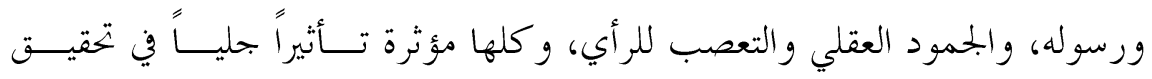
الانحراف الفكري، وسوف يتكون هذا البحث من المطالب الآتية: -

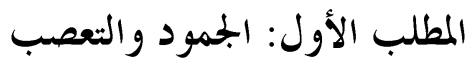

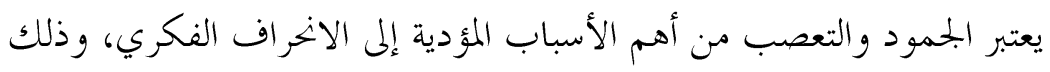

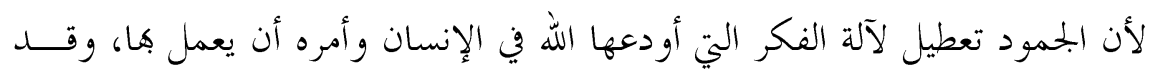

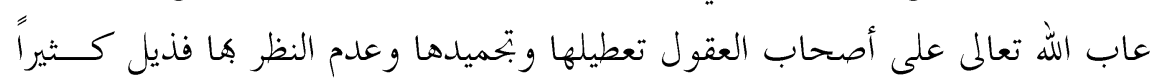

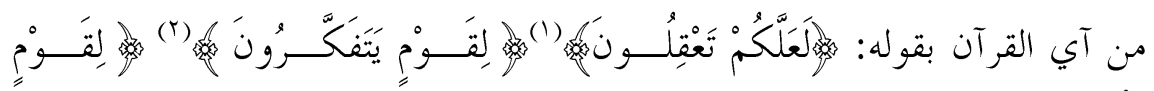

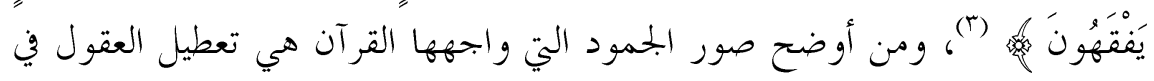

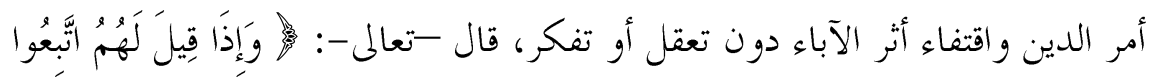

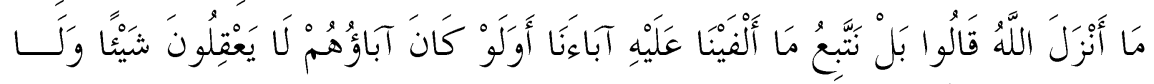

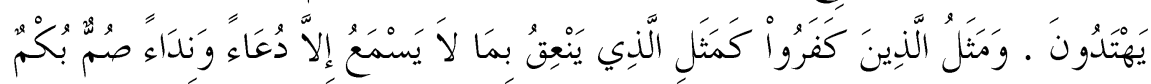

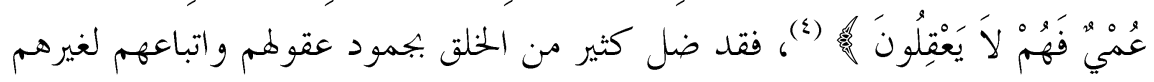

دون نظر (م)

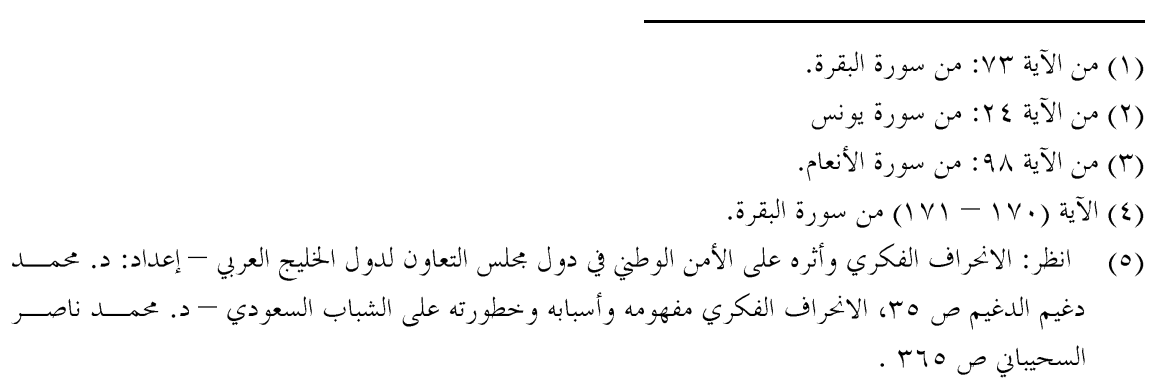




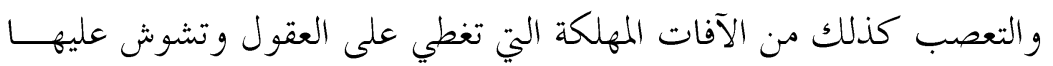
ويحجب رؤيته ويغطي على بصيرته؛ لأن المتعصب لا يرى إلا رأي من يتعصب له، ويندفع في الدفاع عنه دون تفكر ويتحكم فيه الموى لا العقل، وهو من الأمور التي

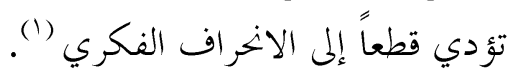
والحق أن الإسلام و اجه التعصب و الجمود أيما مو اجههة، و لم يثبت عن أعسـالام

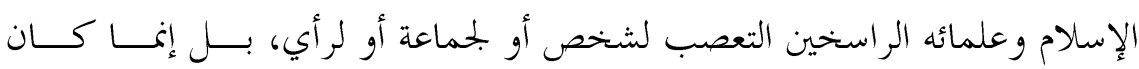

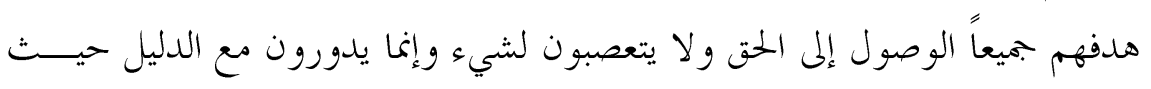
دار.

ونقل الفقهاء رحمهم الله ما وصل إلى حد الاتفاق المعنوي: قــولي صـــواب يكتمل الخطأ وقول غيري خطأ يكتمل الصواب.

وهذا يدل على سعة الأفق وسلامة الفكر والسير على الجــــادة الصــحيحة

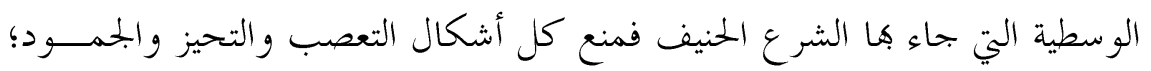

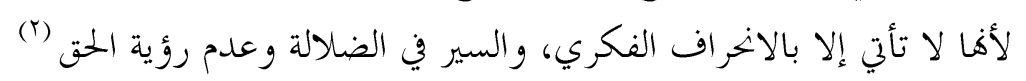
المطلب الثاين

\section{الجهال بالدين ومقاصده.}

إن الجهل بأحكام الشرع وقو اعده ومقاصده من أعظم المزالق التي زلت فيها

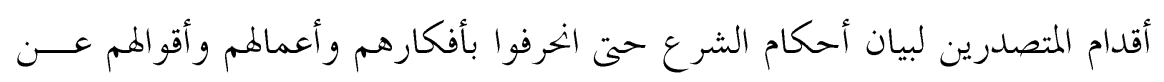

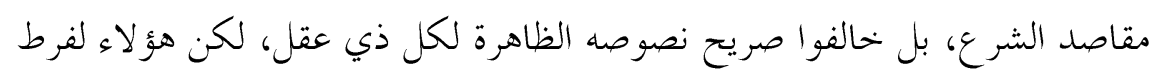

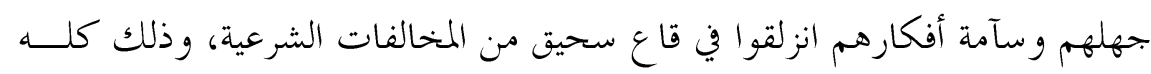
بسبب الجهل الذي لا يستطيعون معه قراءة النصوص الشرعية قراءة سليمة خالية من من فئ اللحن الجلي.

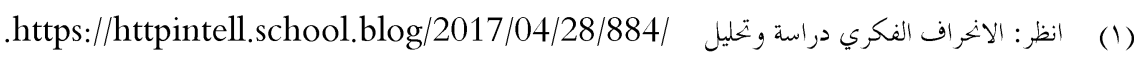

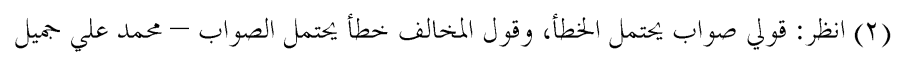
https://www.alukah.net/sharia/0/100937/\#ixzz6YJJNonxU 


\section{الأسباب المعرفية للانحرافات الفكرية ومنهج السنة النبوية في معالجتها}

ولما كان الأمر كذلك جاءت النصوص الشرعية تحذر من الجهل والجاهلين،

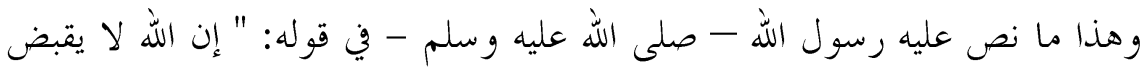

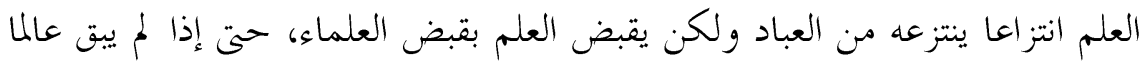

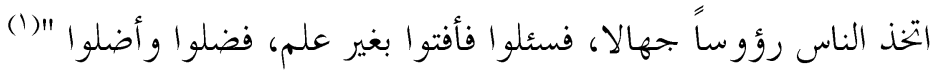

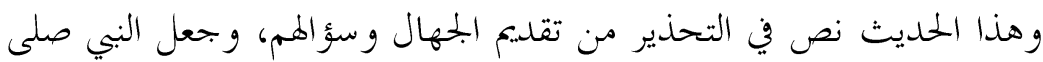

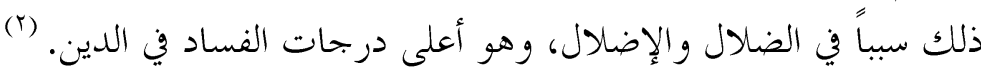
الله عليه وسلم ومسلم

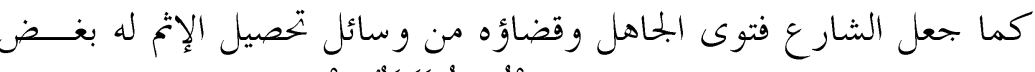

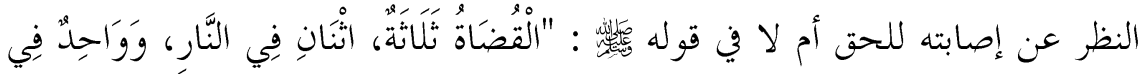

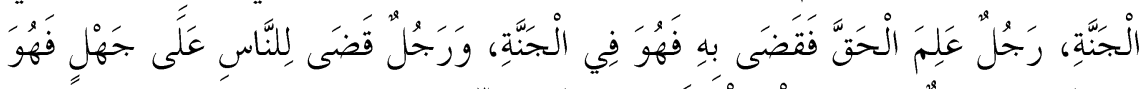

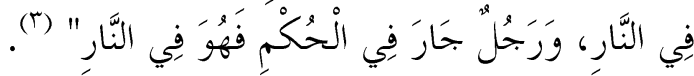

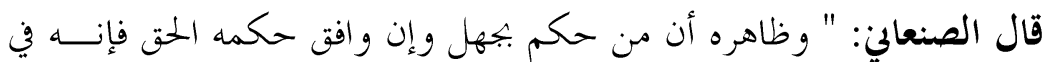

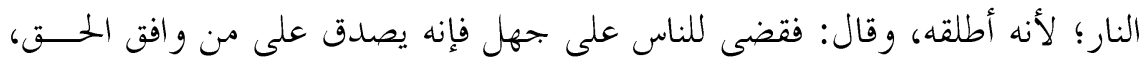

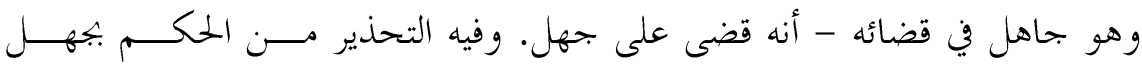

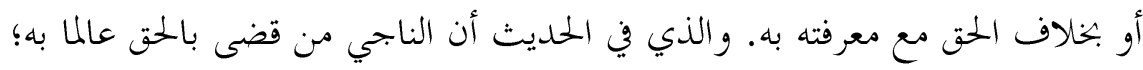

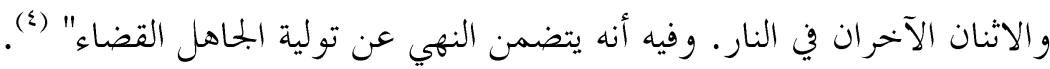

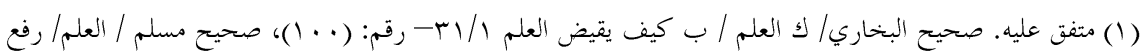

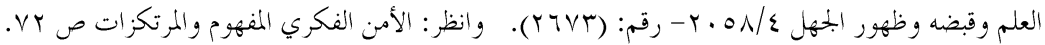

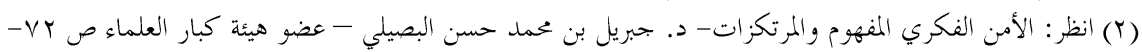

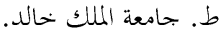

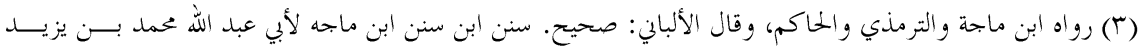

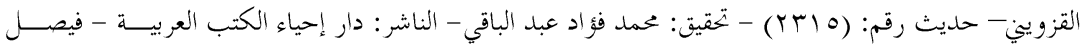

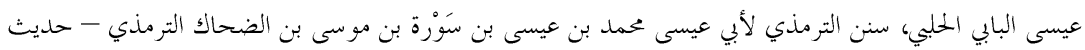

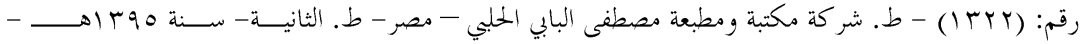

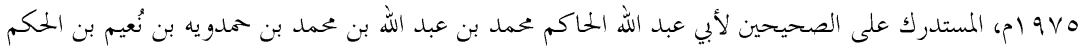

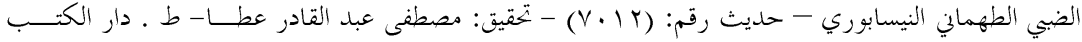

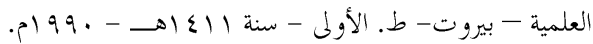

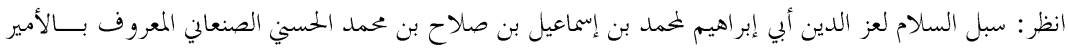

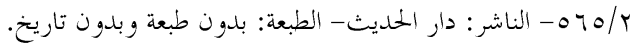




\section{مجلة كلية الدراسات الإسلامية والعربية للبنات بدمنهور العدد الخامس الجزء السادس •r+rم}

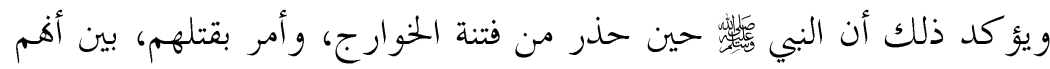

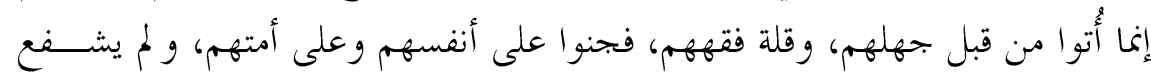

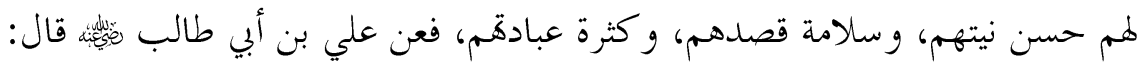

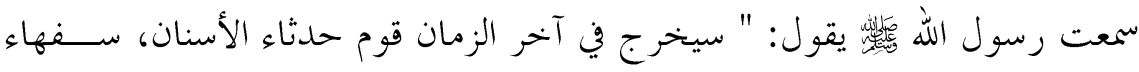

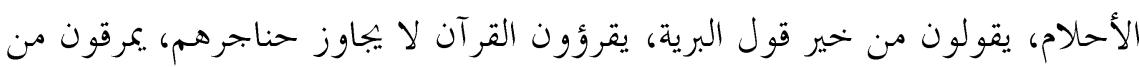

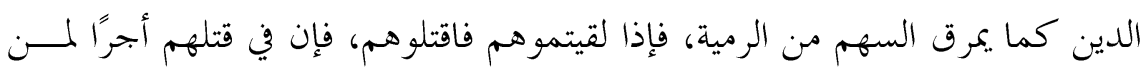

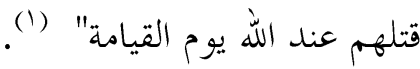

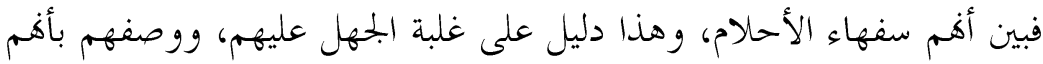

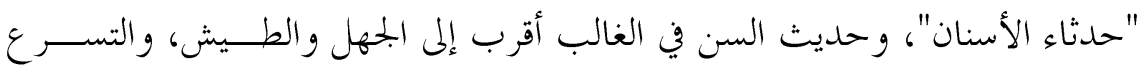

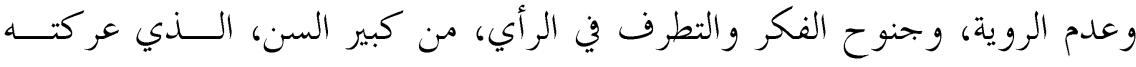

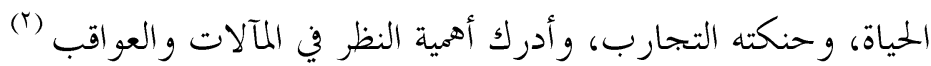
المطلب الثالث

\section{اتباع الموى في الرأي والحكم.}

$$
\text { أولاً: تعريف الهوى: }
$$

الموى لغة: من الفعل هوى يهوى هواية، هوى النفس، ويطلق على ما خــير

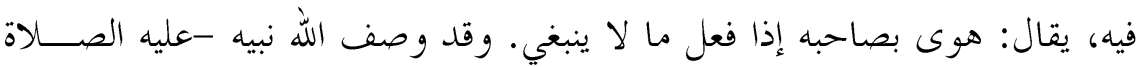

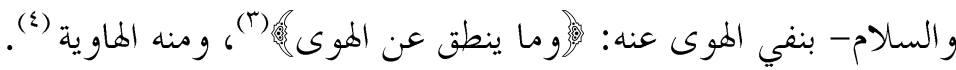

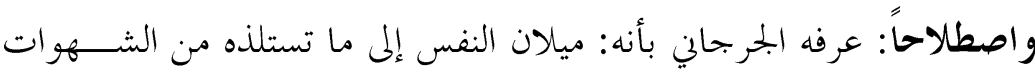
من غير داعية الشرع (ㄷ)

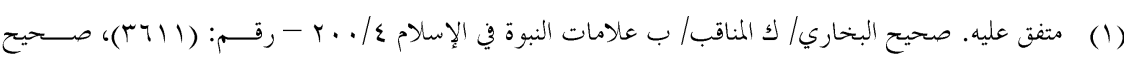

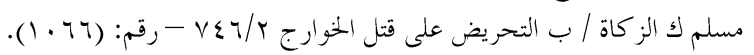

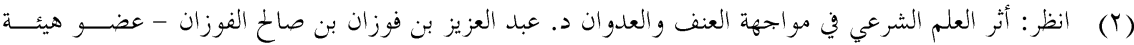

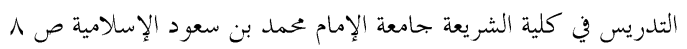

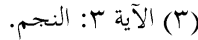

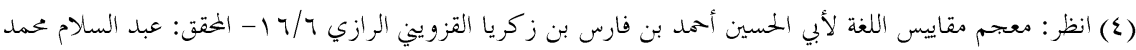

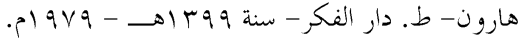

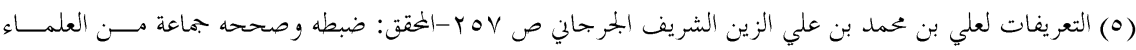

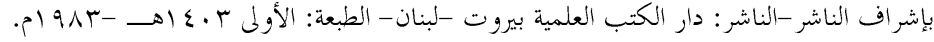


وعرفه أبو البقاء الحنفي بأنه: ميل النَّنس إلى الشَّهوة. يقال: تصرَّف علــى

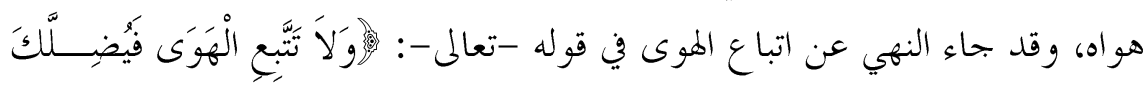

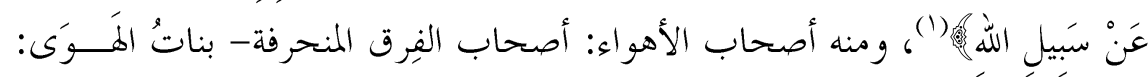

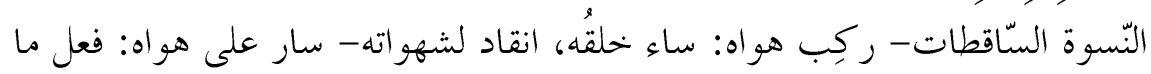

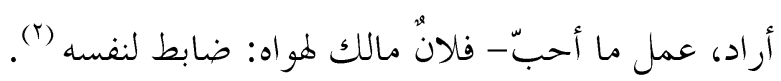

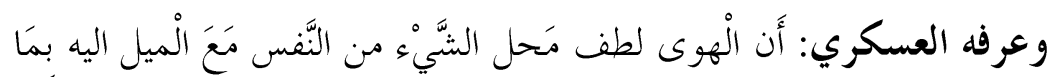

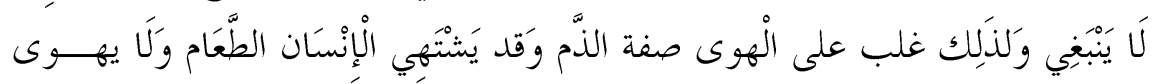

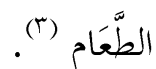

\section{الْفرق بَين الْهوى والثهوة.}

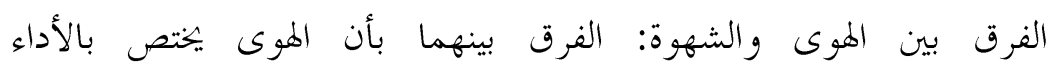
والاعتقادات، والشهوة تختص بنيل المستلذات.

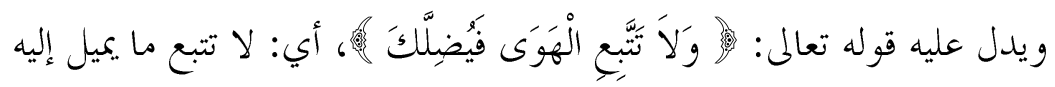

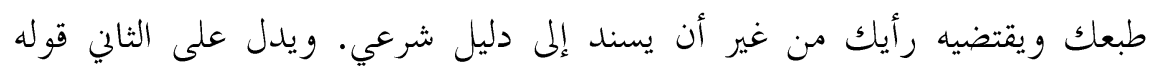

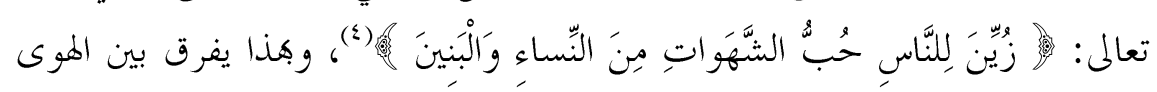
والشهوة (ن)

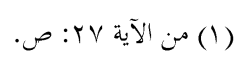

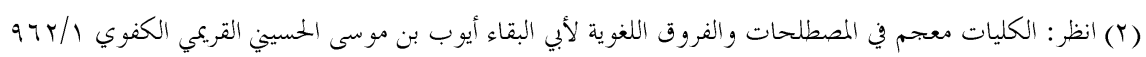

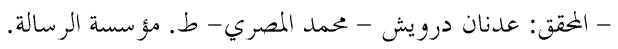

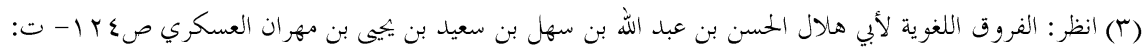

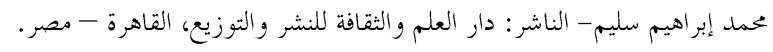

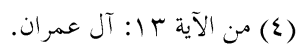

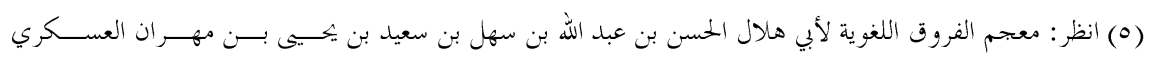

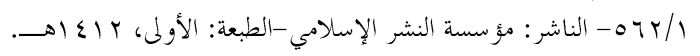




\section{ثانياً: أثر اتباع الموى في الانخر اف الفكري}

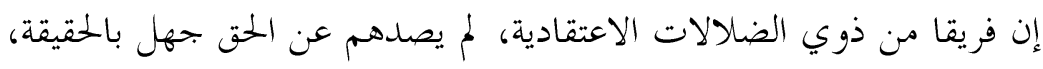

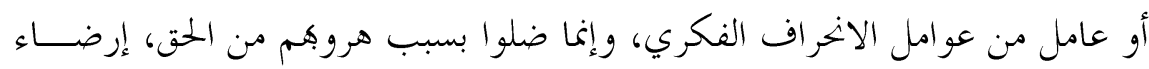

$$
\text { لشهوات نفوسهم، و إتباعا لرغباتهم وأهو ائهم. }
$$

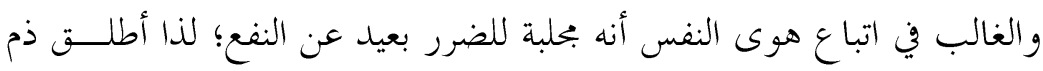

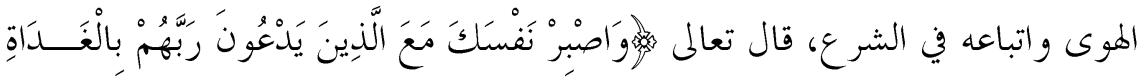

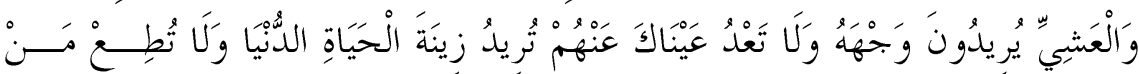

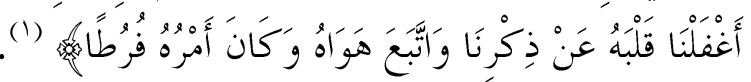

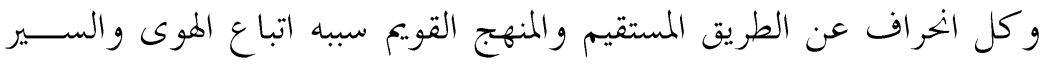

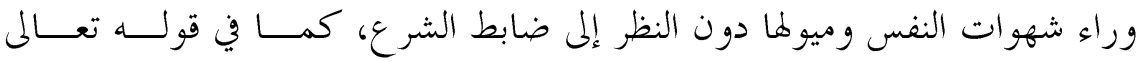

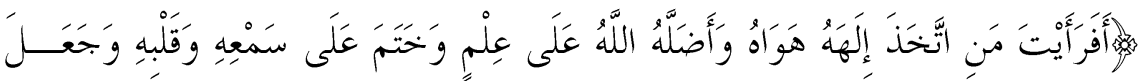

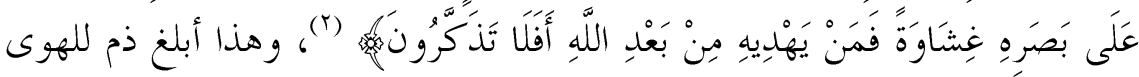
واتباعه (r)

قال ابن رجب: " وإنما تنشأ الذنوب من محبة ما يكرهه الله، أو كراهة ما يحبه

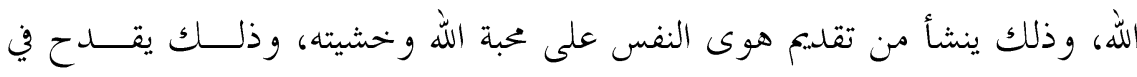

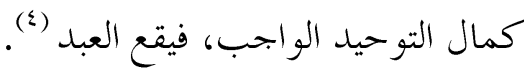
ولما كان للاتباع هذا الأثر في مخالفة الحق و اتباع الباطل و الضلال والإضلال،

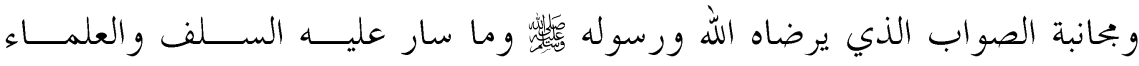

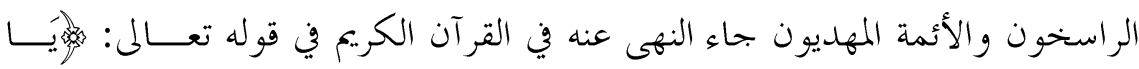

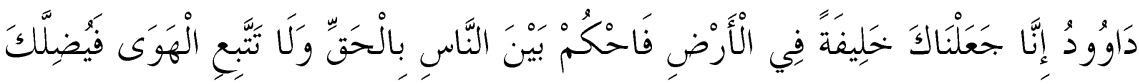

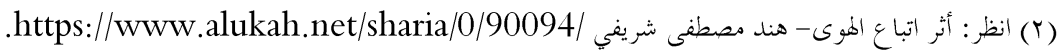

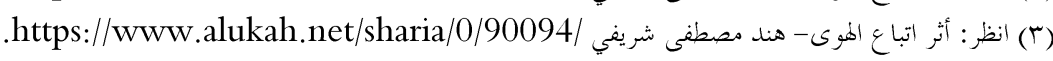

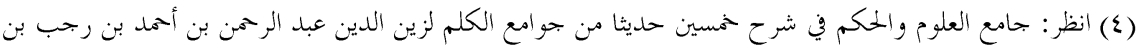

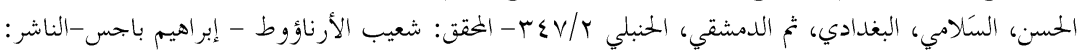

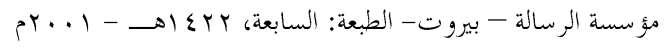




\section{الأسباب المعرفية للانحرافات الفكرية ومنهج السنة النبوية في معالجتها}

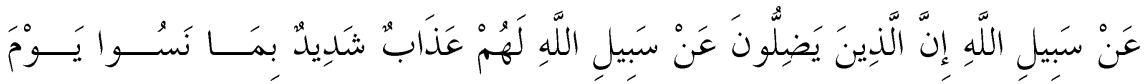
(1)

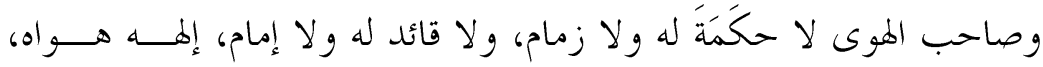

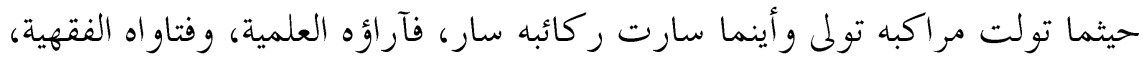

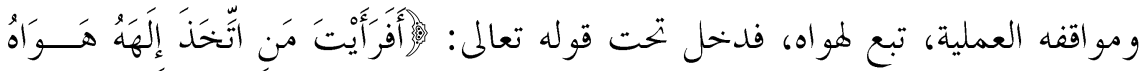

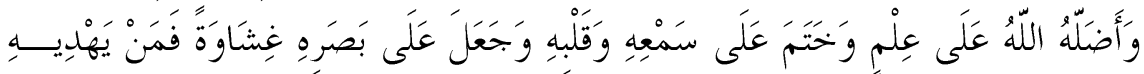

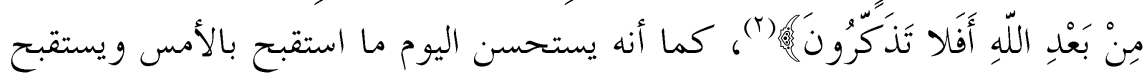

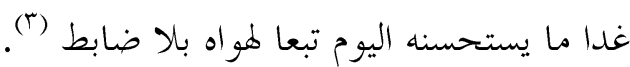
كما أن صاحب الموى ليس له معايير ضابطة، ولا مقاييس ثابتة، يردّ الدليل

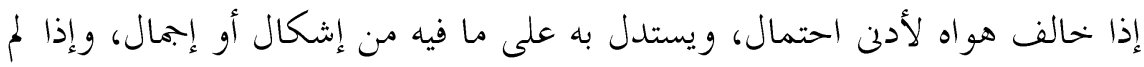

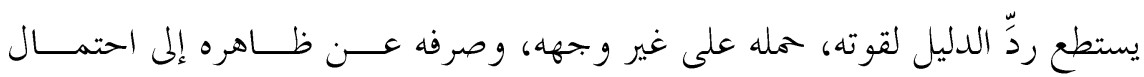
مرجوح بغير دليل.

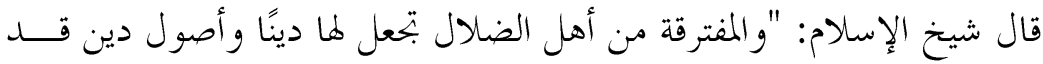

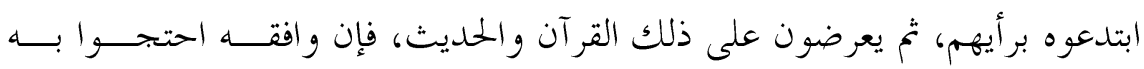

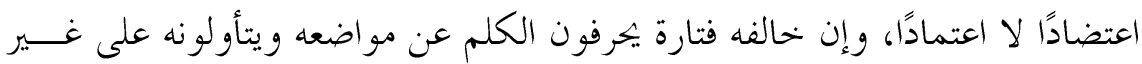

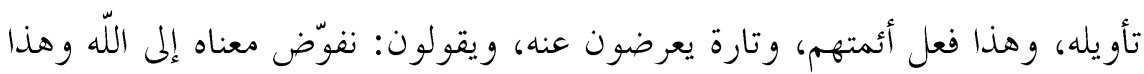

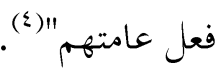

صاحب الهوى ضال مضل صاحب ضلالة داع إلى فتنـــة مفـــرق لجماعـــة

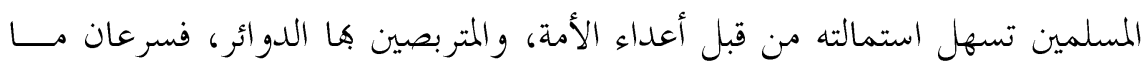

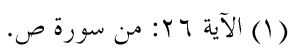

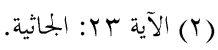
(T) انظر: التباع الهوى الشيخ الدكتور إبراهيم بن عبدالله الزهر اني https://dorar.net/article/173/\%D8\%A7\%D8\%AA\%D8\%A8\%D8\%A7\%D8\% B9-\%D8\%A7\%D9\%84\%D9\%87\%D9\%88\%D9\%89

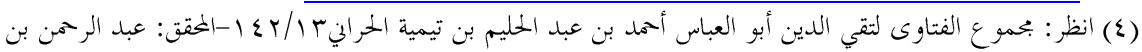

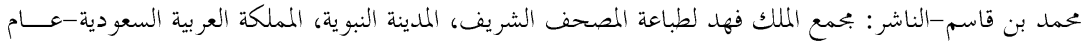


يرتد خنجراً في خاصرة الأمة، وسوطاً يلهبُ ظهرَها، وعيناً يكشف سرها، ويـــــي

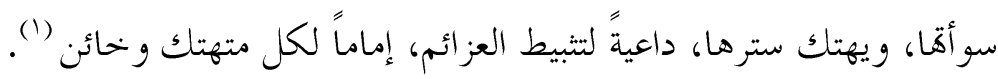

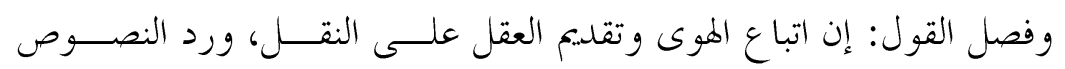

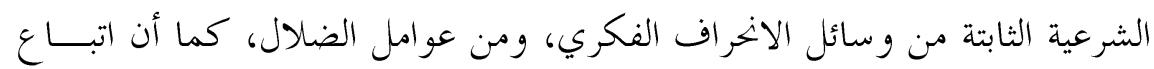

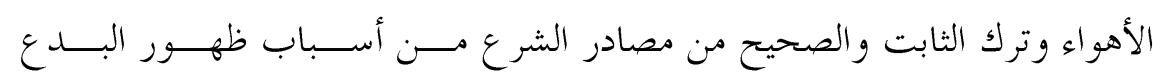

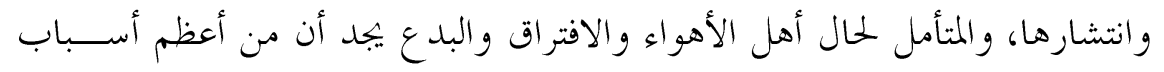

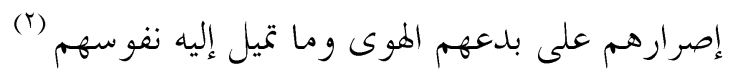
B9-\%D8\%A7\%D9\%84\%D9\%87\%D9\%88\%D9\%89 (r) (الاغر اف وانقسام الأمة د. كمد سعد عبد اللطيف http://www.alnoor.se/article.asp?id=187115 


\section{الأسباب المعرفية للانحرافات الفكرية ومنهج السنة النبوية في معالجتها}

\section{المبحث الثالي}

\section{الأسباب المعرفية الخارجية للانحر افات الفكرية}

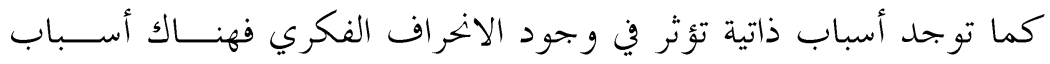

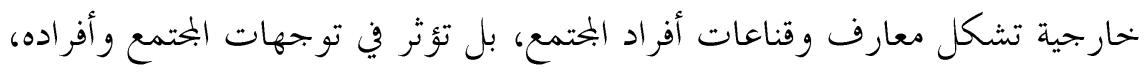

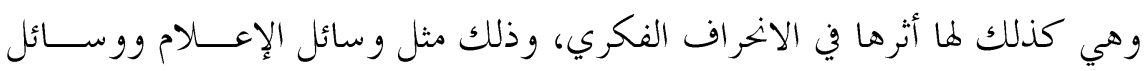

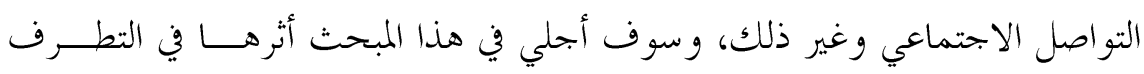
والانحراف الفكري من خلال المطالب الآتية: -

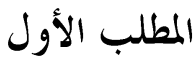

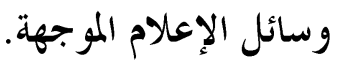

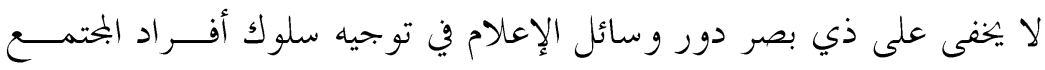

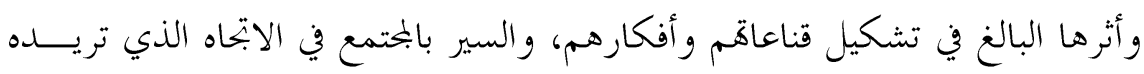

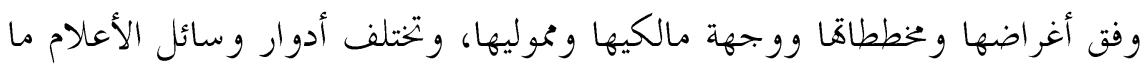

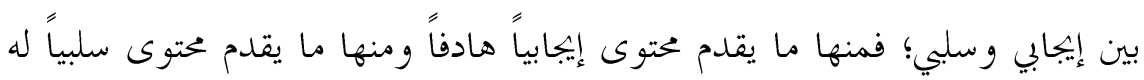

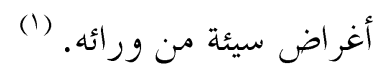
ولا شك أن تأثير وسائل الإعلام على مبادئ وقيم الإنسان واضح لأن تلك ألك

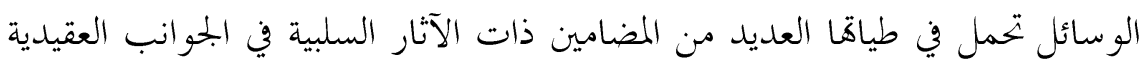

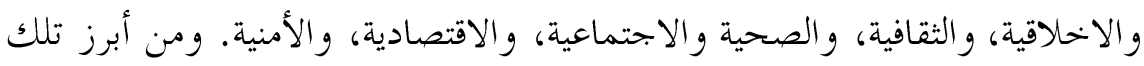

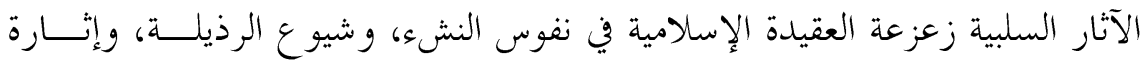

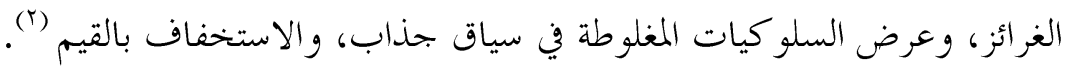

(1) (1) تأثير الإعلام على الجتمع إيمان الحياري https://mawdoo3.com/\%D8\%AA\%D8\%A3\%D8\%AB\%D9\%8A\%D8\%B1_\%D8 \%A7\%D9\%84\%D8\%A5\%D8\%B9\%D9\%84\%D8\%A7\%D9\%85_\%D8\%B9 \%D9\%84\%D9\%89_\%D8\%A7\%D9\%84\%D9\%85\%D8\%AC\%D8\%AA\%D9 \%85\%D8\%B9 (Y) الانخر اف الفكري مغهومه وأسبابه وخطورته على الشباب السعودي - د. كمد ناصر السحيباني ص TYV. 
والناظر إلى العالم من حوله يرى كثرة وسائل الأعلام زيادة مفرطــة حستى

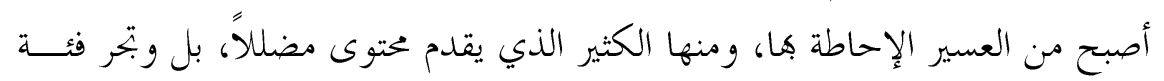

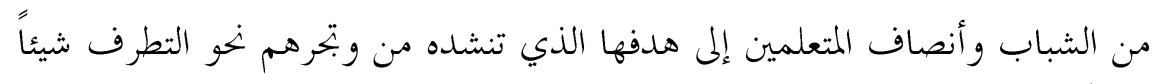
فشيئاً حتى تخرجهم من جملة المعتدلين إلى حظيرة المنحرفين.

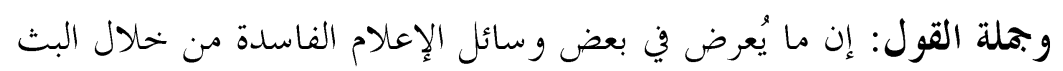

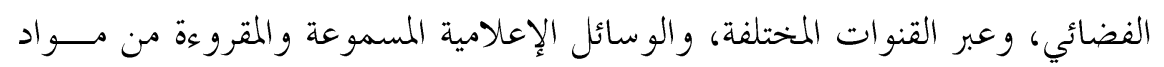

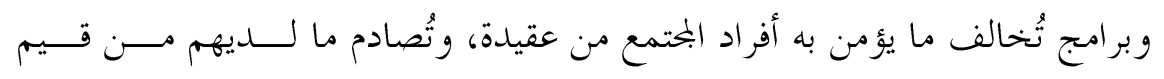

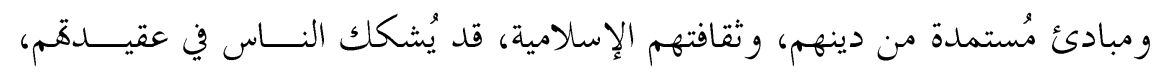

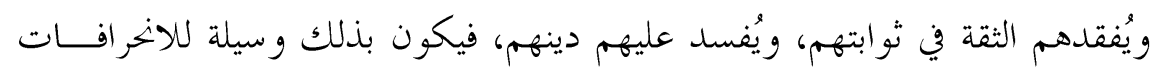
الفكرية و السلو كية (1)

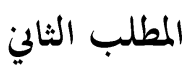

\section{وسائل التواصل الاجتماعي.}

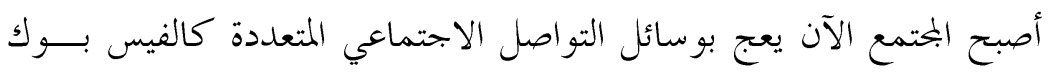

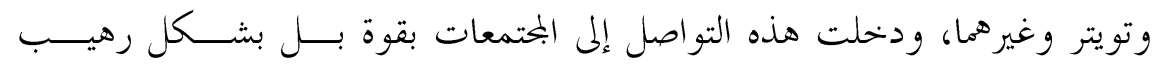

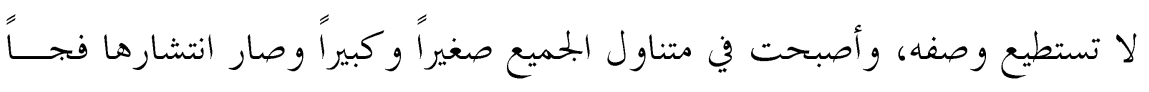
لا أقول في كل بيت بل في كل غرفة.

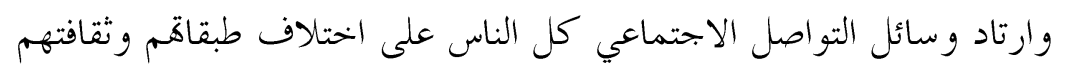

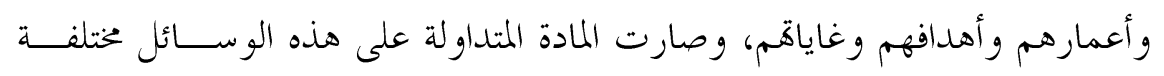

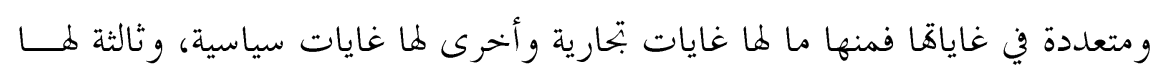

$$
\text { غايات دينية إلى غير ذلك. }
$$

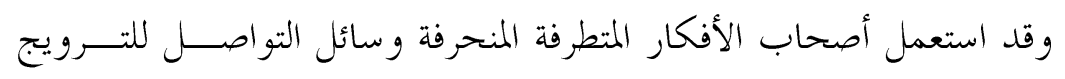

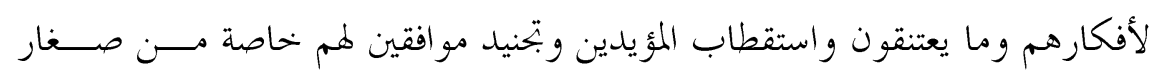
السن والشباب قليلي العلم ضعاف الخبرة الذين تنطلي عليهم هذه الأفكار.

http://www.alnoor.se/article.asp?id=187115 (1) الانخراف وانقسام الأمة د. محمد سعد عبد اللطيف 


\section{الأسباب المعرفية للانحرافات الفكرية ومنهج السنة النبوية في معالجتها}

كما صار لها من الآثار السلبية على المختمع الكثير كإطلاق الأخبار دون تثبت

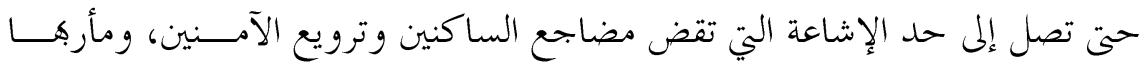

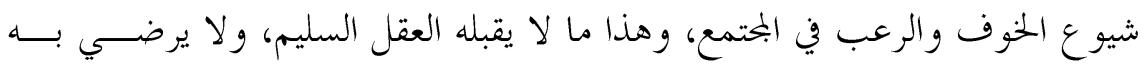

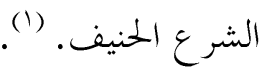

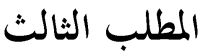

\section{ضعف دور المؤسسات الدعوية.}

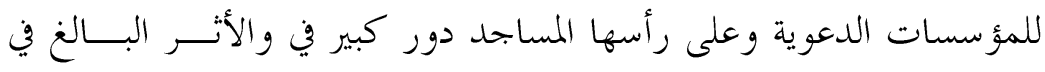

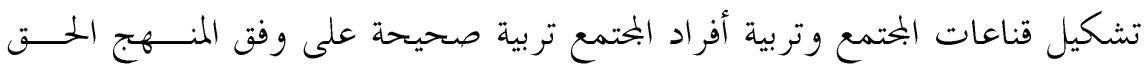

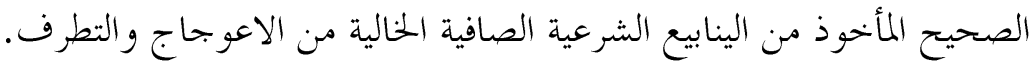

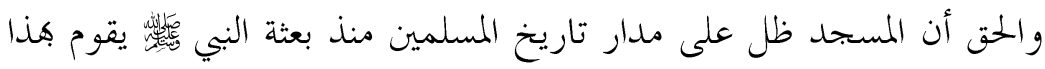

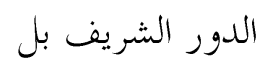

تحاوز ذلك فقد كان المسجد جامعة تدرس فيه العلوم على اختلافها أنواعها الشرعية وغيرها، وكم تخرج من العلماء المبزرين في تاريخ الإسلام من المساجد.

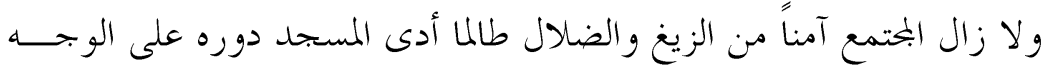

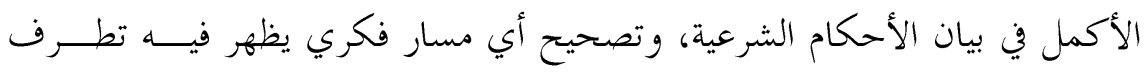
أو الخر اف. في

ولما ضعف دور المسجد في البناء العقلي والفكري لأفر اد الجتمع أصبح أفــــاد

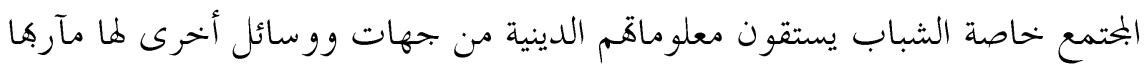

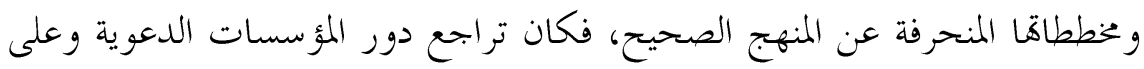

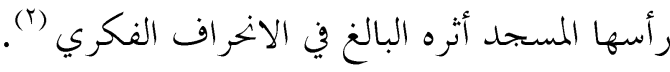

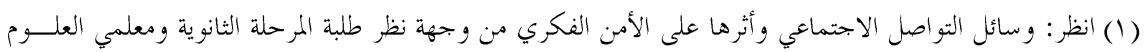

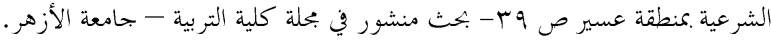

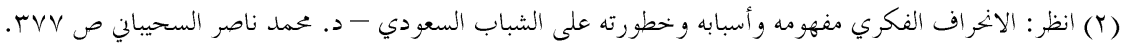


مجلة كلية الدراسات الإسلامية والعربية للبنات بدمنهور العدد الخامس الجزء السادس •r.rم

المبحث الثالث

\section{منهج السنة النبوية في معالجة الأسباب المعرفية للانحر افات الفكرية}

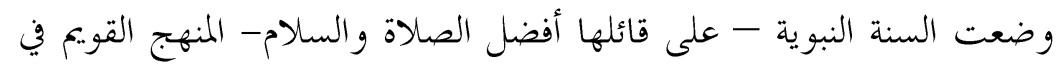

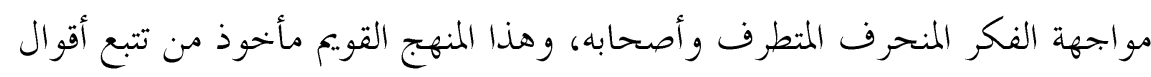

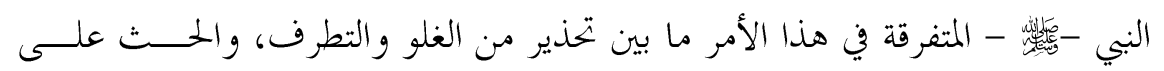
العلم الشرعي، وسوف ينقسم هذا المبحث إلى المطالب الآتية:

\section{المطلب الأول}

\section{التحذير من الغلو والتطرف.}

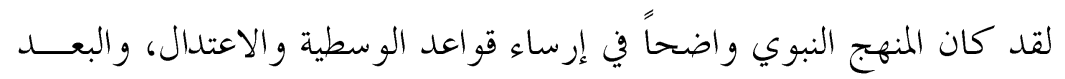

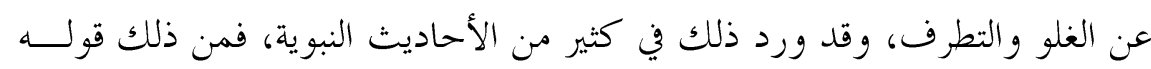

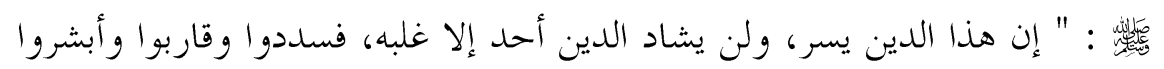

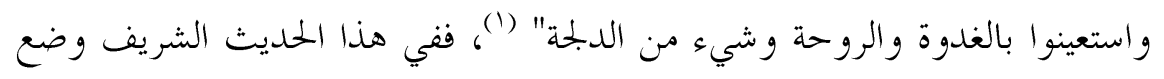

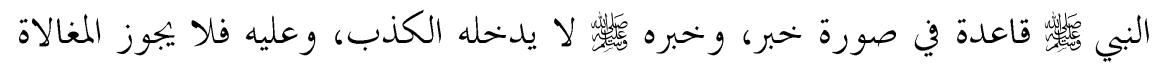
في أحكامه بما يناقض هذه القاعدة المقررة.

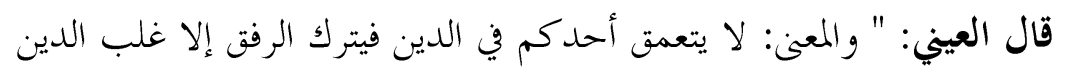

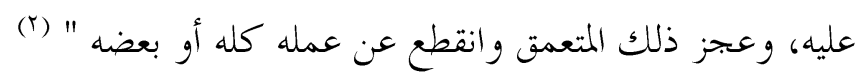

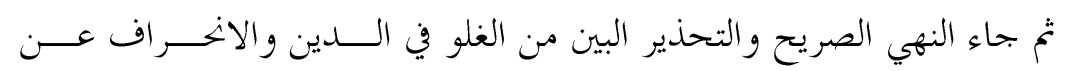

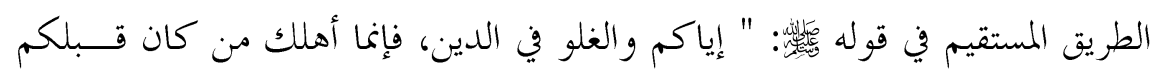

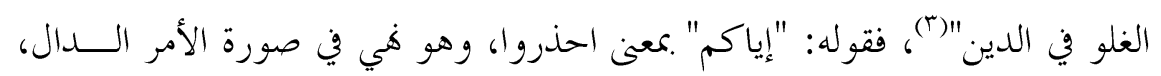

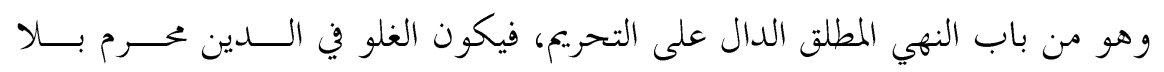
خلاف أخذاً من منطوق وصريح النهي الوارد في الحديث.

(1) رواه البخاري. صحيح البخاري- ب: الدين يسر - حديث رقم: (بح). (1).

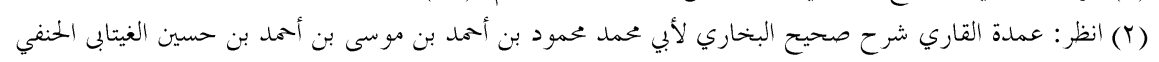

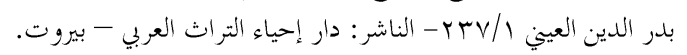

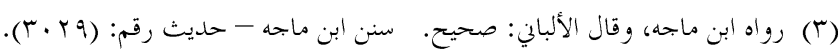


قال ابن بطال: " وذلك أن الغلو في الدين مذموم و التشديد فيه غير محمــود

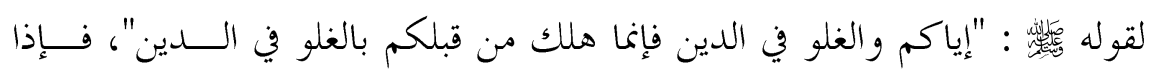

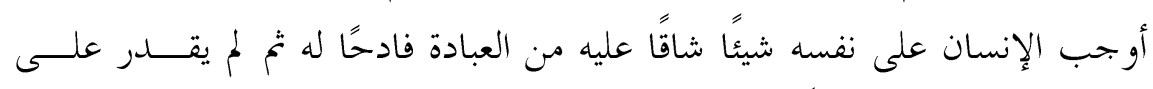

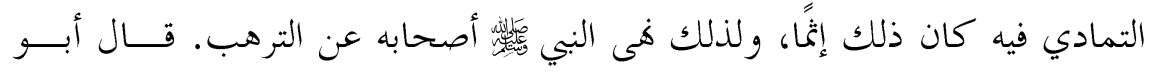

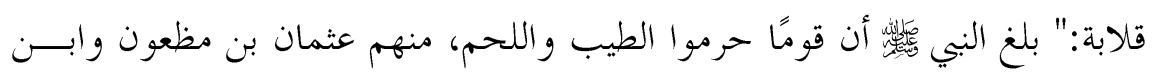

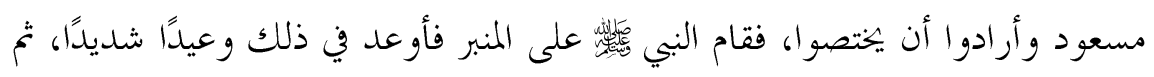

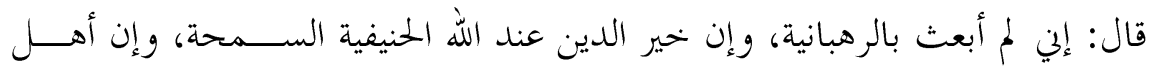

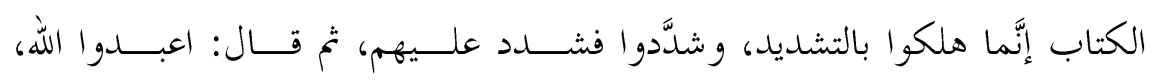

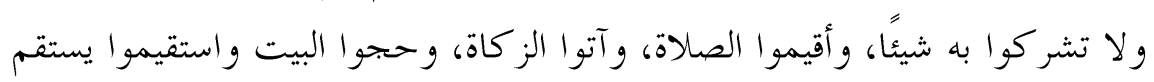

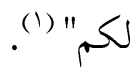

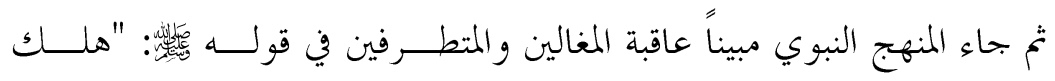

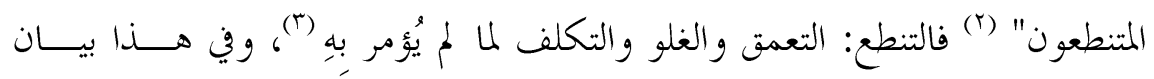

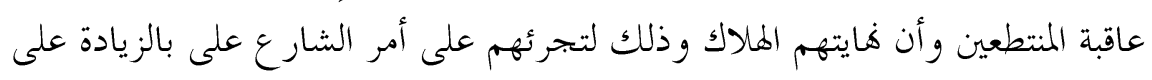
الفعل أو النقصان عنه. وعلى ذلك يمكن تلخيص المنهج النبوي في مواجهة الغلو والتطرف فيما يلي: -

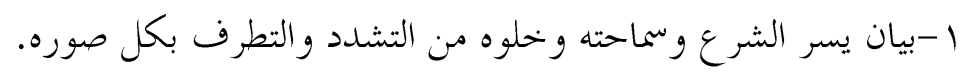
r-النهي عن الغلو والتطرف هياً مطلقاً يفيد تحريمه.

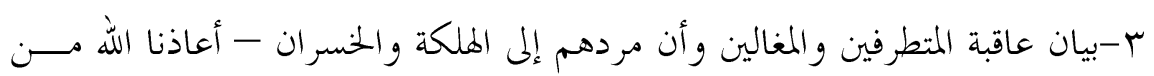
ذلك- .

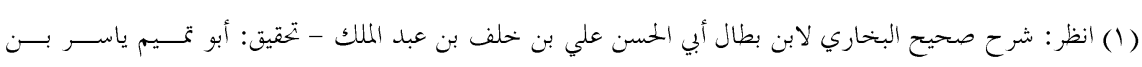

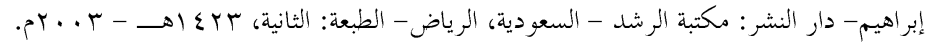

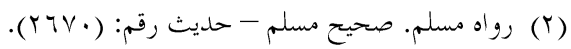

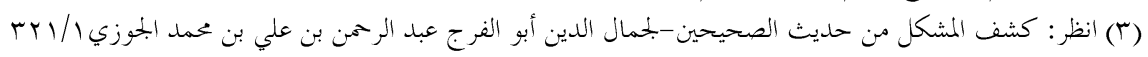

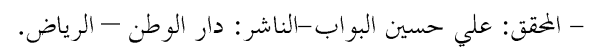




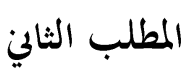

\section{الحثث على طلب العلم الشرعي.}

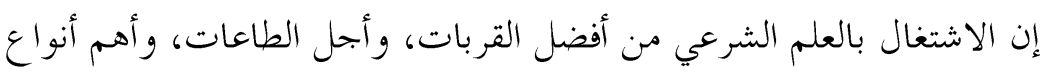

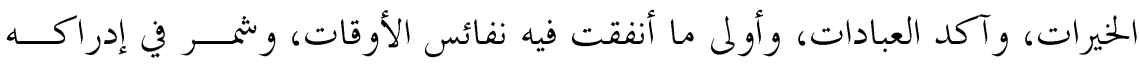

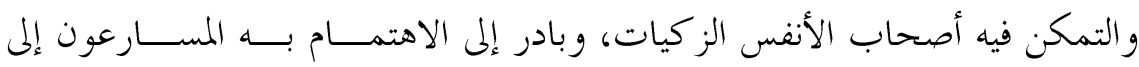

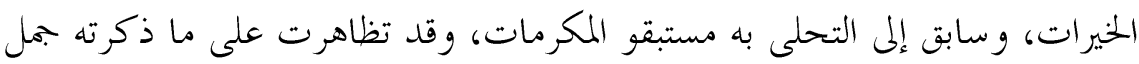

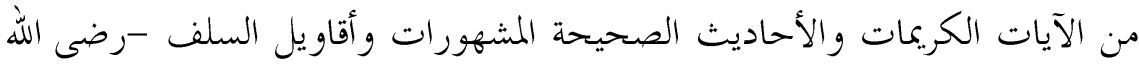

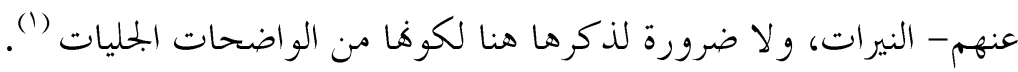

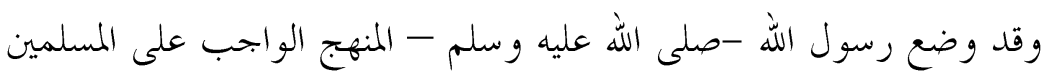

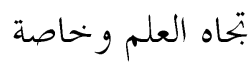

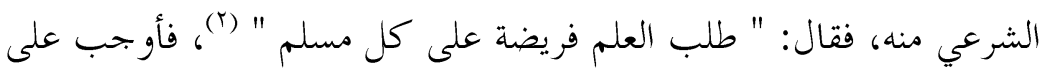

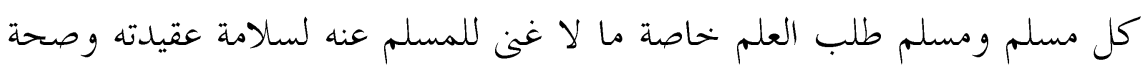

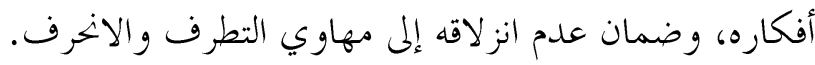

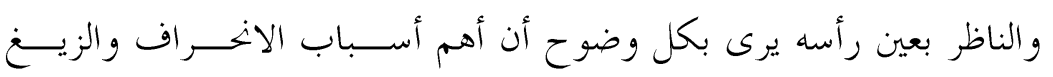

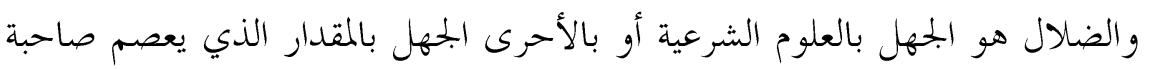

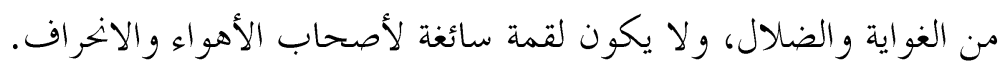

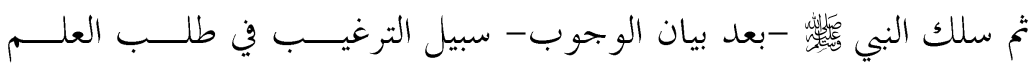

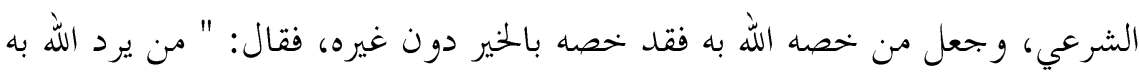

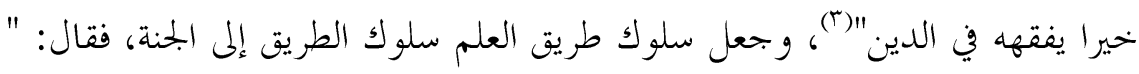

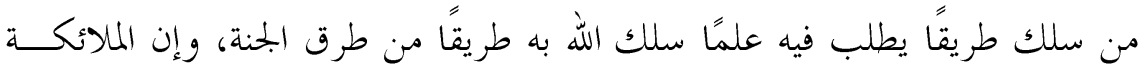

(1) انظر: المنهاج شرح صحيح مسلم بن الحجاج لأبي زكريا محيي الدين يميى بن شرف النووي / الب- ط. دار إحيـاء

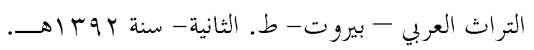

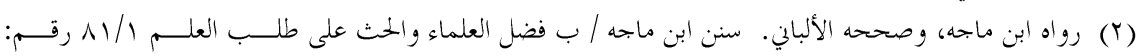

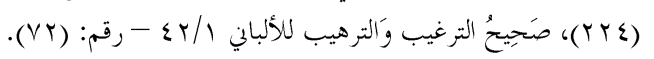

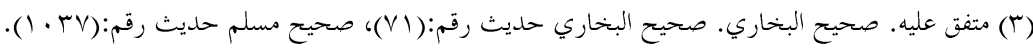




\section{الأسباب المعرفية للانحرافات الفكرية ومنهج السنة النبوية في معالجتها}

لتضع أجنحتها رضًا لطالب العلم، وإن العالم ليستغفر له من في السماوات ومــن في

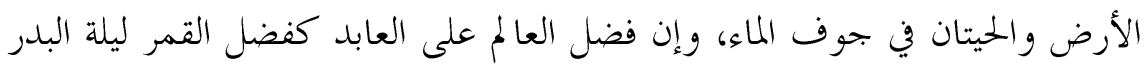

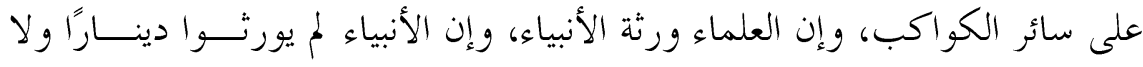

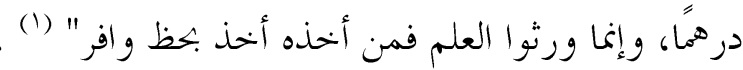
وجملة القول: إن العلم الشرعي وسيلة عصمة العقل من الزلل والانحـــاف، وقد سلكت السنة في ذلك منهجين: الأول: بيان حكم طلب العلم الشرعي. والثاني:

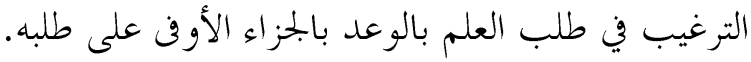

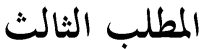

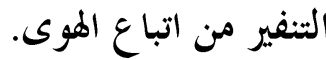

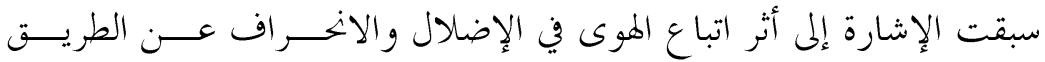

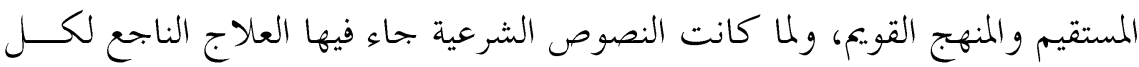

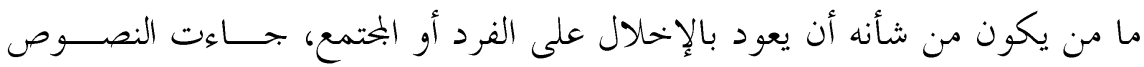

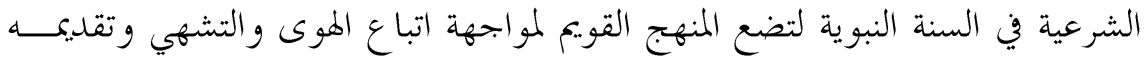
على النص الشرعي؛ إذ هذا هو الانخر اف والضلال.

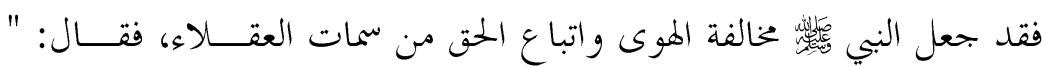

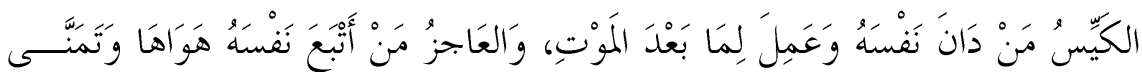

عَكلى اللهّ" (r)

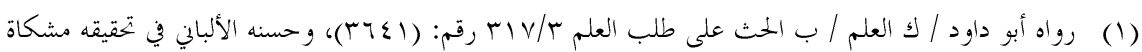

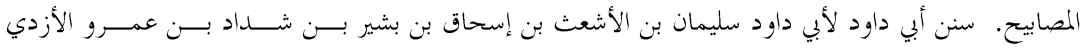

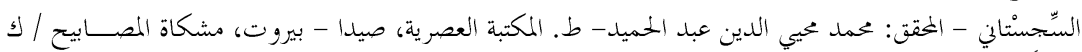
العلم

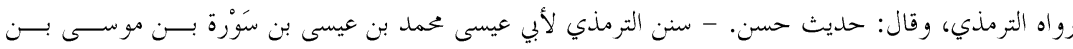

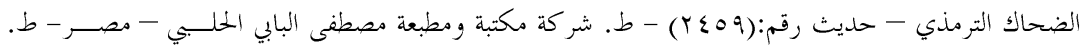

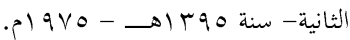




\section{مجلة كلية الدراسات الإسلامية والعربية للبنات بدمنهور العدد الخامس الجزء السادس •r.rم}

ثم نحت السنة منحا آخر في مواجهة اتباع الهوى، وذلك ببيان فضيلة مخالفـــة

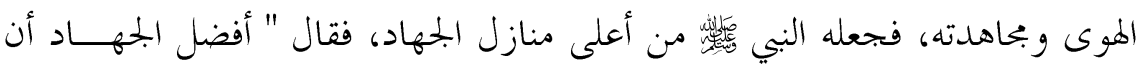
بجاهد الرجل نفسه وهواه " (1)

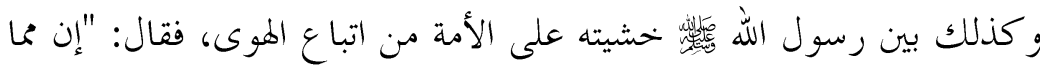

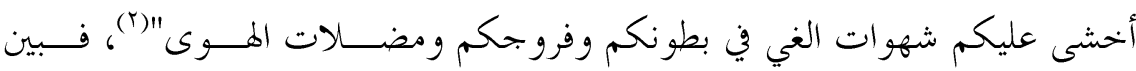

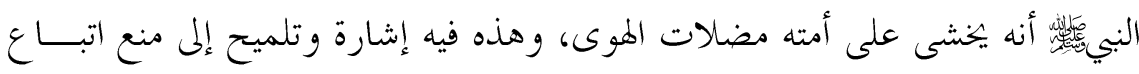
الهوى بغير هدى الله، و التنفير من ذلك لما بيجره من الضلال على ملى صاحبه.

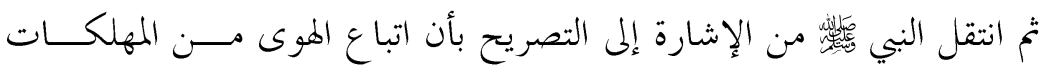

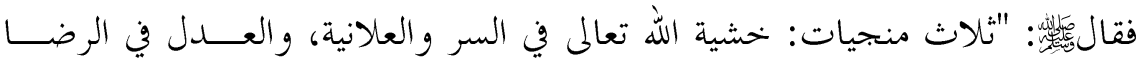

و الغضب، و القصد في الفقر و الغنى وثلاث مهلكات: هوى متبــع و شـــح مطــــاع،

وإعجاب المرء بنفسه" (r)

ثم نحت السنة منحا آخر في مواجهة اتباع الهوى، وذلك ببيان فضيلة مخالفـــة

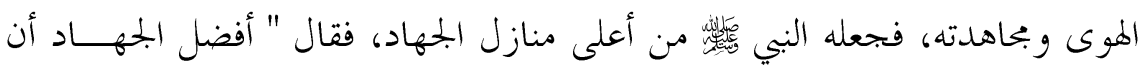

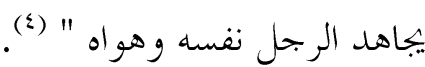

وبذلك يتلخص منهج السنة النبوية في مواجهة اتباع الهوى في بيان فضــيلة

مخالفة الفوى واجتناب ما يملي به على صاحبه، ثم الإشارة إلى ضـــرره ثم التصـــريح بخطره المؤدي إلى إيراد النفوس موارد التهلكة.

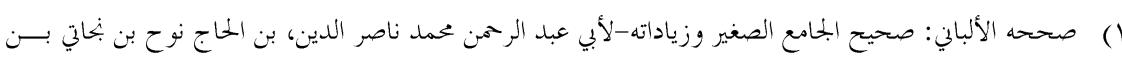

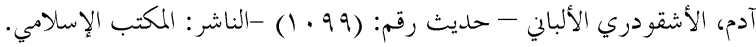

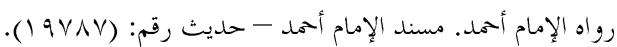

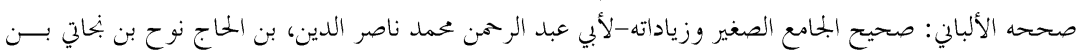

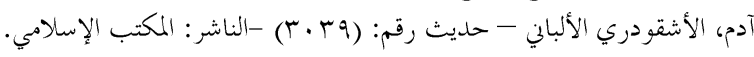

$$
\begin{aligned}
& \text { صححه الألباني: صحيح الجامع الصغير وزياداته - حديث رقم: (99 (19. (1). }
\end{aligned}
$$




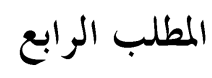

\section{إبراز العلماء الراسخين.}

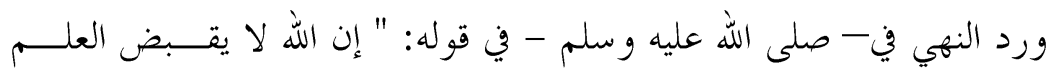

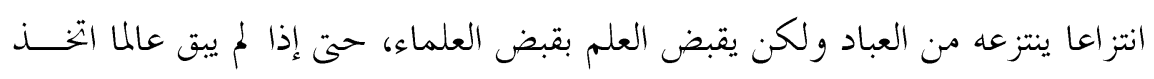

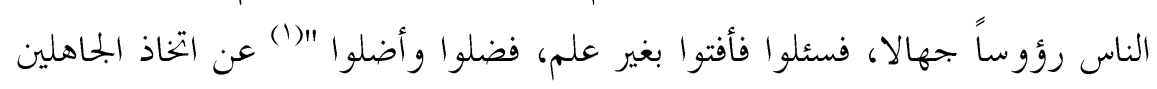

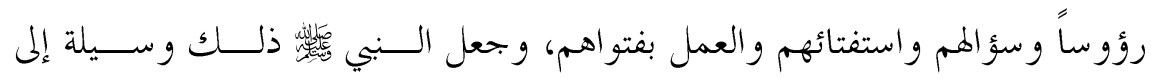
الضلال والإضلال، وهذا هو قمة الانحر اف الفكري.

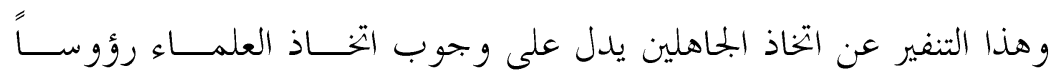

$$
\text { وسؤالهم، وطلب الفتوى منهم و الرجوع إليهم في النوازل. }
$$

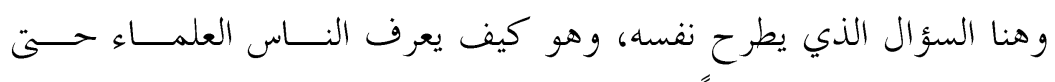

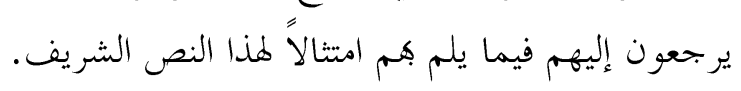

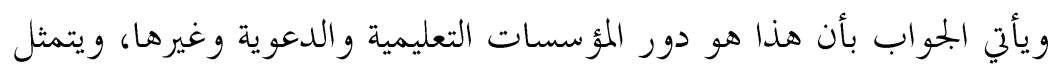

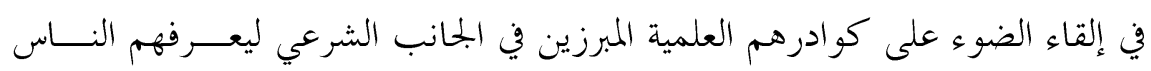

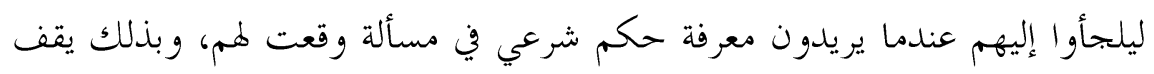

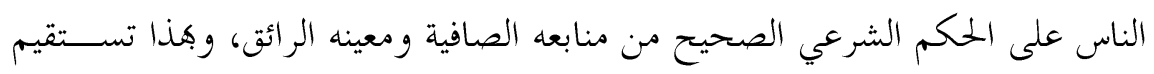

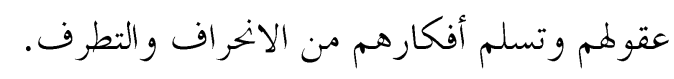

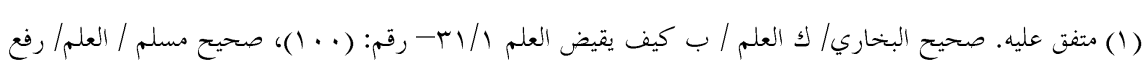

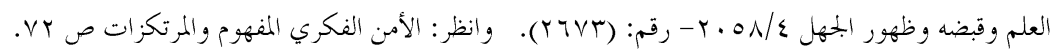


مجلة كلية الدراسات الإسلامية والعربية للبنات بدمنهور العدد الخامس الجزء السادس •r.rم

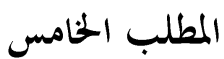

\section{ضوابط استخدام وسائل التواصل من السنة النبوية}

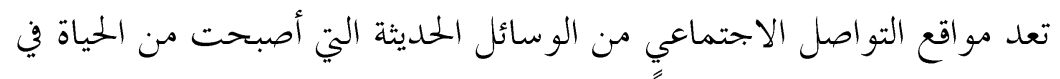

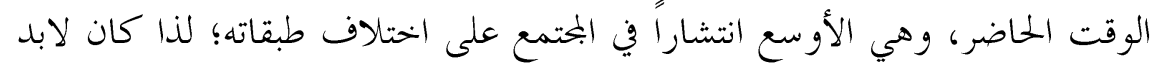

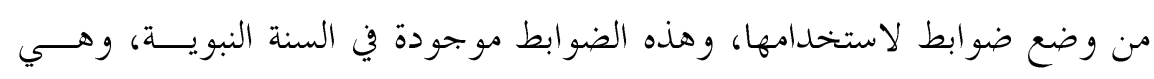

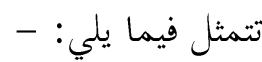

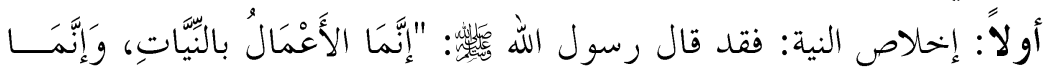

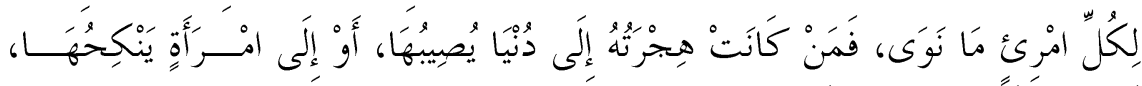

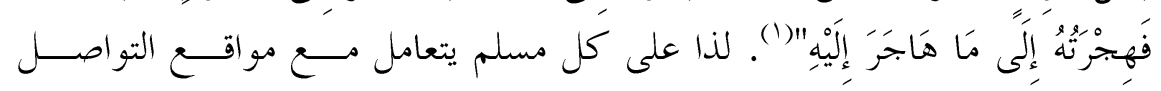

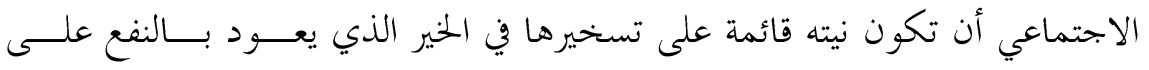

ثانياً: استغلال هذه الوسائل في نشر المختوى المفيد الصحيح شرعاً وتجنب نشر الصنا

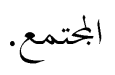

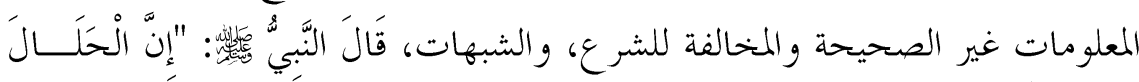

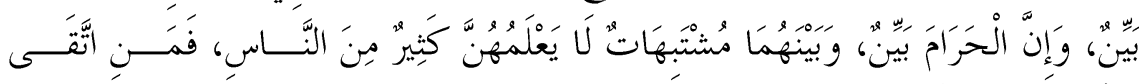

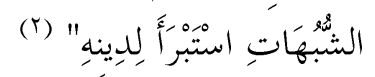
ثالثاً: الالتزام بالأخلاق الإسلة الإلامية من الصدق والأمانة، والابتعاد عن الألفاظ

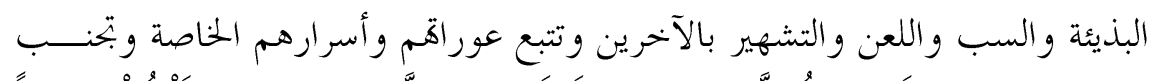

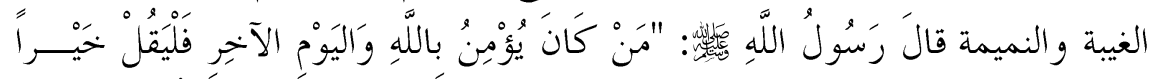

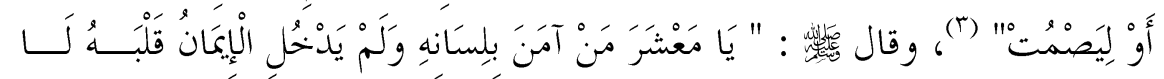

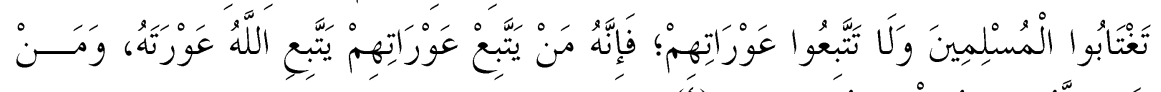

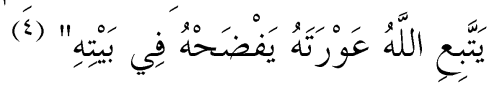

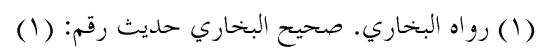

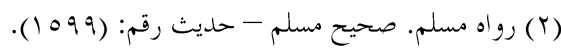

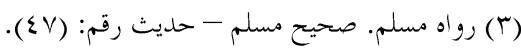

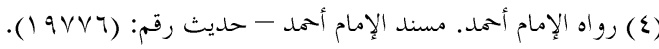




\section{الأسباب المعرفية للانحرافات الفكرية ومنهج السنة النبوية في معالجتها}

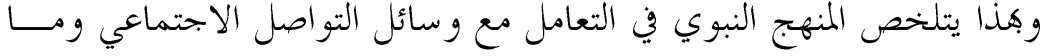

شاهها في الإخلاص وقصد الخير، واستغلال تلك الوسائل في النفع والمصلحة الــتي

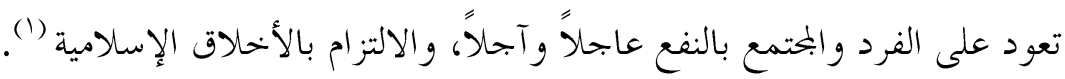
المطلب السادس

\section{التعريف بمذاهب أهل الغلو والتنفير منها.}

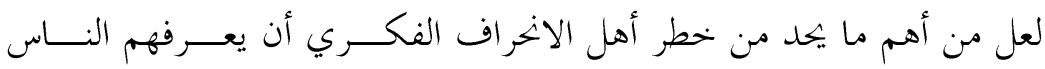

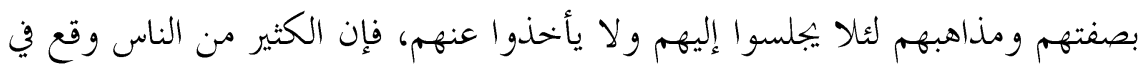

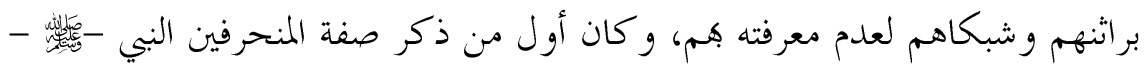

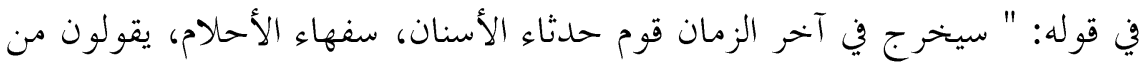

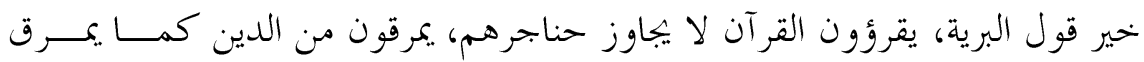

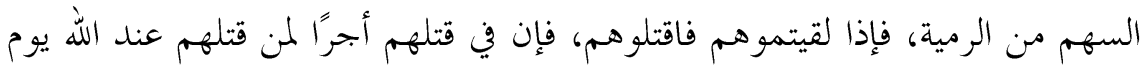

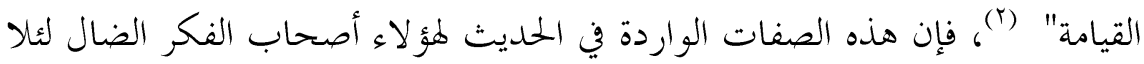

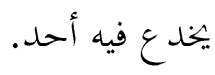
وذكر المنحرفين وصفاهم والتشهير بهم قد فعله الصحابة، فقد كان علي بن

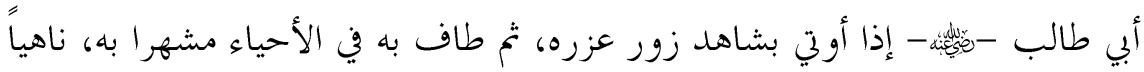

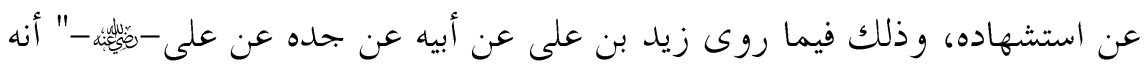

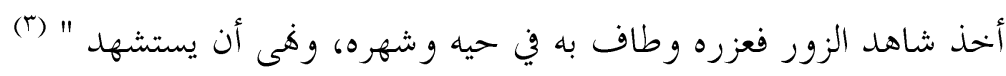

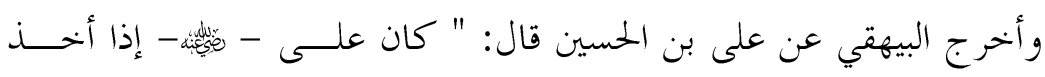

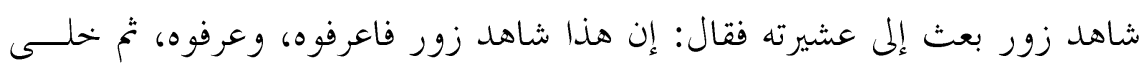

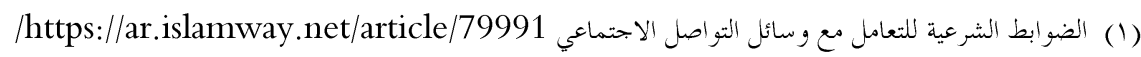

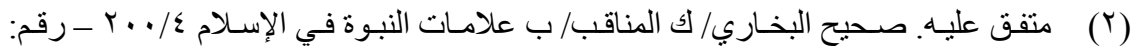

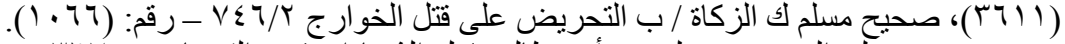

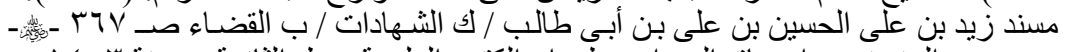

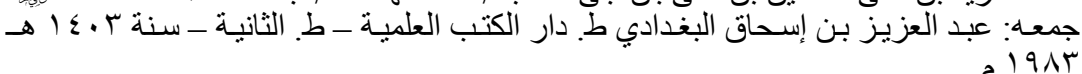




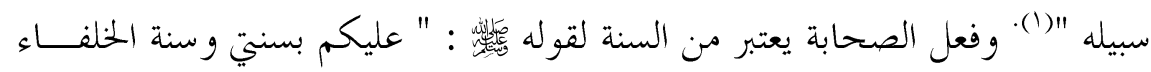

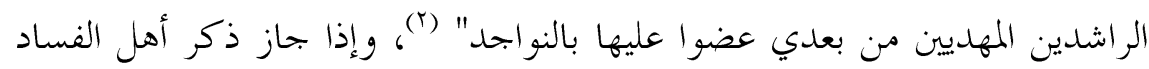

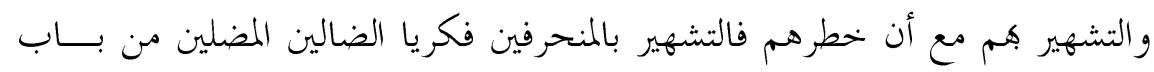
(َ) أو ألى

فجملة المنهج في هذا الشأن بيان صفات أهل الضلال والاخر اف والتنفير من

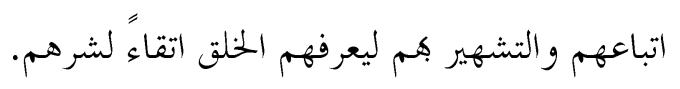

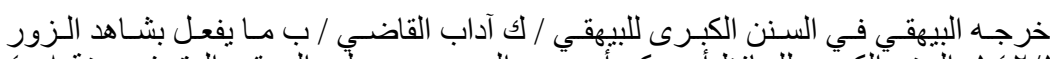

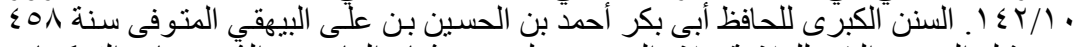

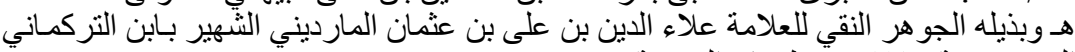

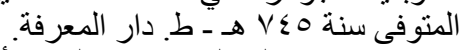

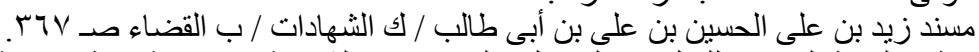

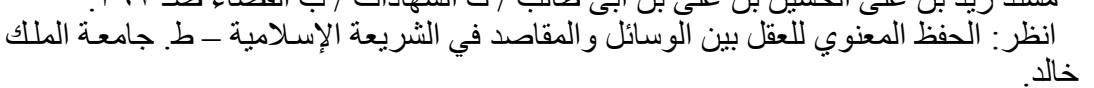




\section{الأسباب المعرفية للانحرافات الفكرية ومنهج السنة النبوية في معالجتها}

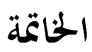

الحمد لله الذي بنعمته تتم الصالحات، والصلاة والسلام على أشرف الأنبيــاء إعهاء

وسيد المرسلين، وعلى آله وصحابته ومن استن بسنته إلى يوم الدين، أما بعد:

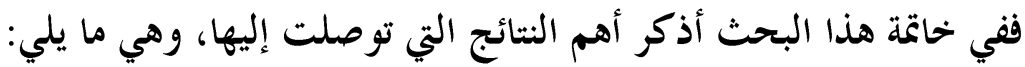

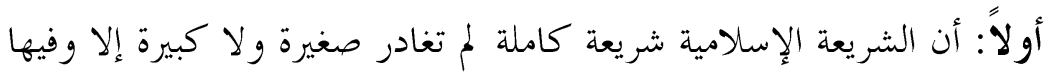

ثانيا: أن الأمن الفكري وحماية الفرد والمختمع من الانخراف الفكري ضرورة

ثالثا: أن هناك الكثير الوسائل المعرفية المؤدية إلى الانحراف الفكري والعقدي.

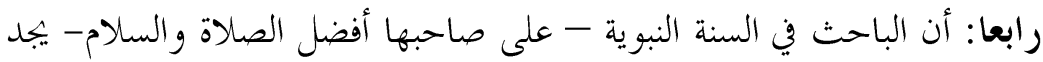

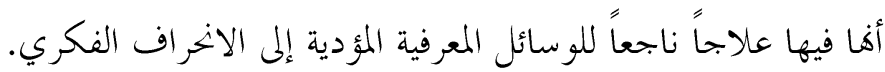

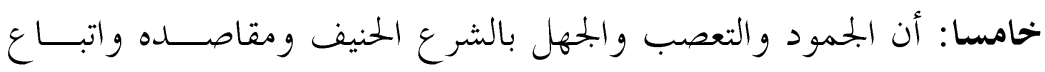

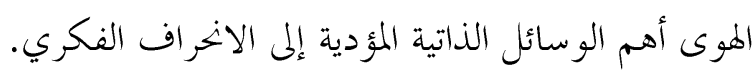

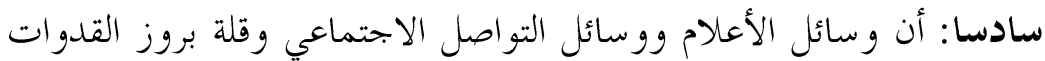

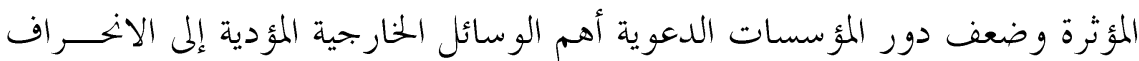
الفكري.

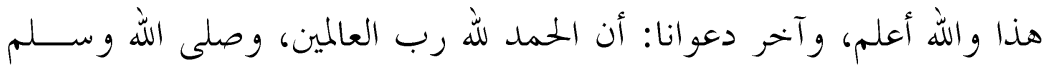

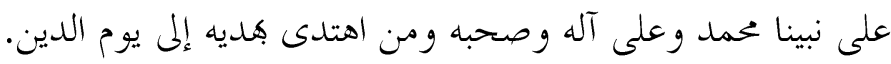

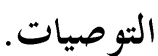

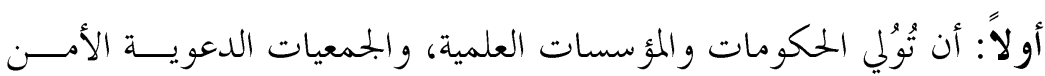

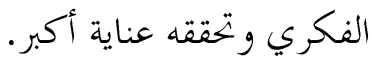

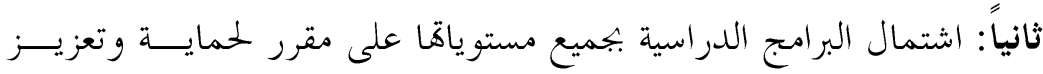

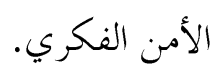

ثالثاً: إبراز العلماء الراسخين لتشكيل القدوات في البحتمع خاصة الشباب.

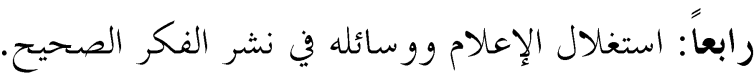


مجلة كلية الدراسات الإسلامية والعربية للبنات بدمنهور العدد الخامس الجزء السادس •r.rم

\section{فهرس المراجع والمصادر}

-الإهماج في شرح المنهاج لتقي الدين أبو الحسن علي بن عبد الكافي بن علي بن تمام

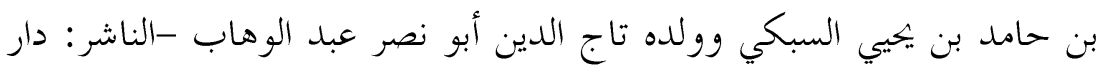

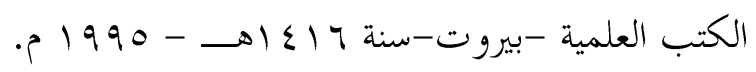

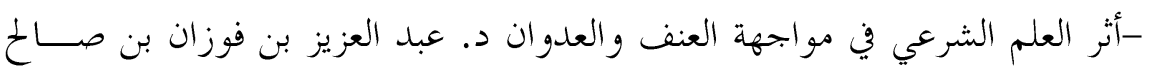

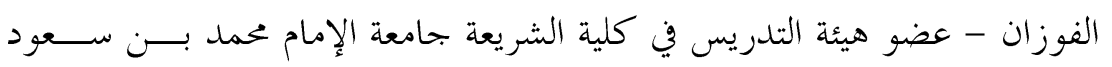

$$
\text { الإسلامية }
$$

- الإحكام في أصول الأحكام المؤلف: أبو الحسن سيد الدين علي بن أبي علي بــن الإنس

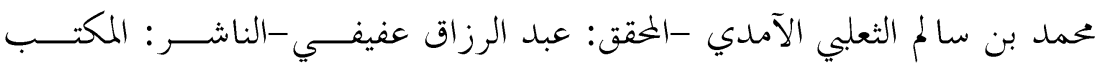

$$
\text { الإسلامي، بيروت- دمشق - لبنان. }
$$

- الأزمة الفكرية المعاصرة د. طه العلواني - ط. المعهد العالمي للفكر الإســلامي - سئل

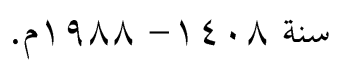

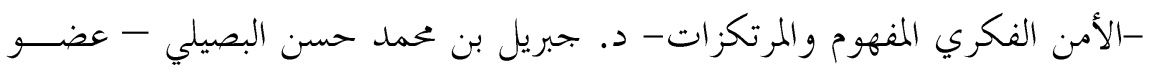

$$
\text { هيئة كبار العلماء- ط. جامعة الملك خالد. }
$$

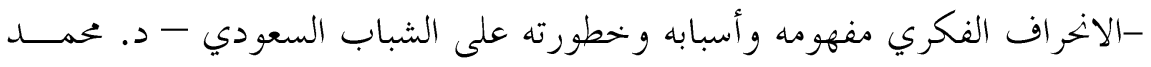

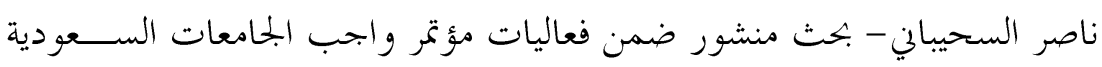

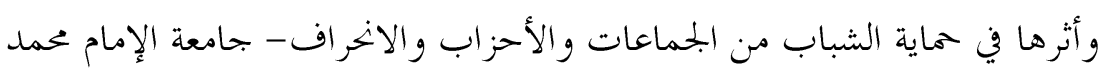

$$
\text { بن سعود الإسلامية. }
$$

-الانخر اف الفكري وأثره على الأمن الوطني في دول بحلس التعاون لـــدول الخلــيج

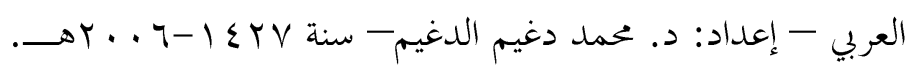

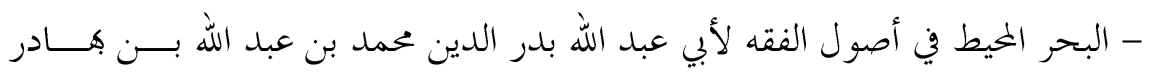

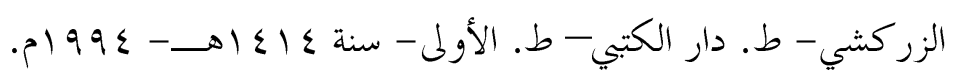

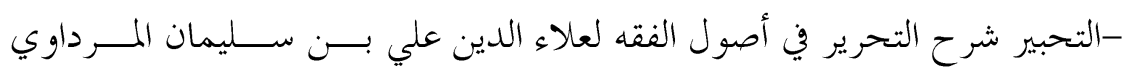

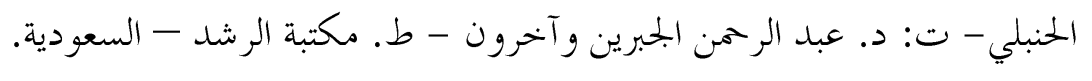

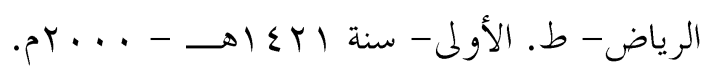




\section{الأسباب المعرفية للانحرافات الفكرية ومنهج السنة النبوية في معالجتها}

- التطرف الفكري أسبابه ومظاهره وسبل مواجهته دراسة من منظور الكتاب والسنة - د. نادي محمود حسن - أستاذ التفسير وعلوم القرآن- كلية أصول الــــين.

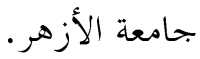
-التعريفات لعلي بن محمد بن علي الزين الشريف الجرجاني-المحقق: ضبطه وصححه

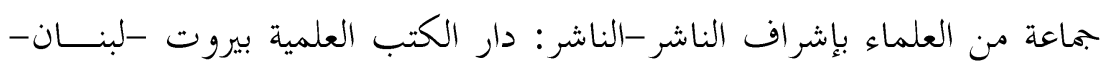

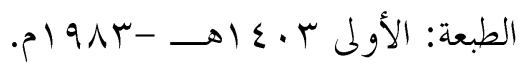

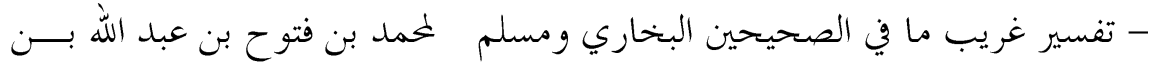

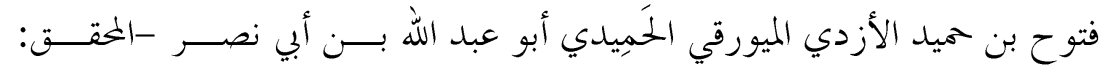

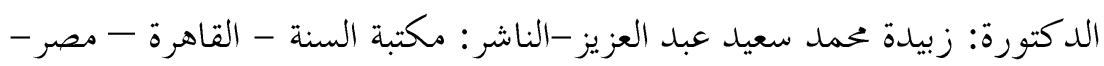

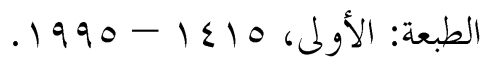

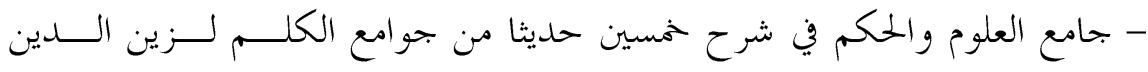

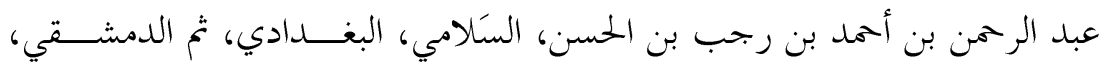

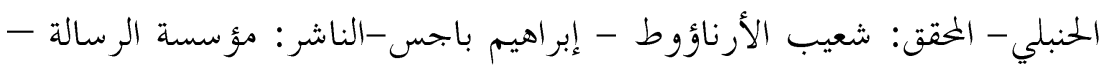

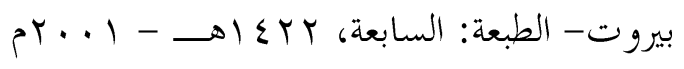

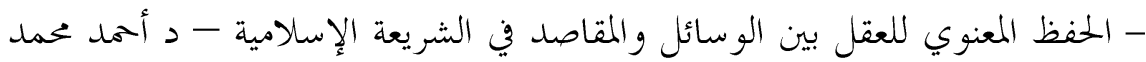
عزب- ط. جامعة الملك خالد.

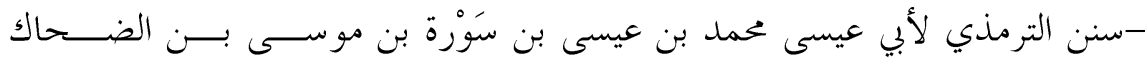

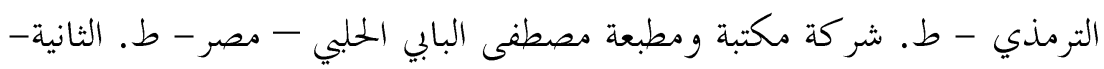

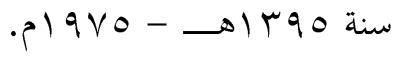

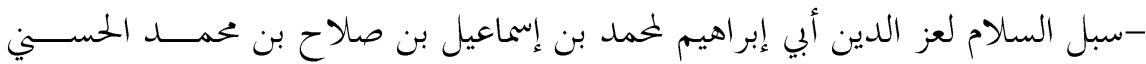

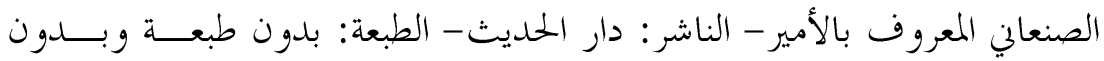

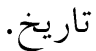

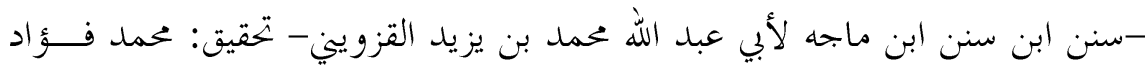
عبد الباقي - الناشر: دار إحياء الكتب العربية - فيصل عيسى البابي الحلبي. 
-سنن أبي داود لأبي داود سليمان بن الأشعث بن إسحاق بن بشير بن شـــداد بــنـ

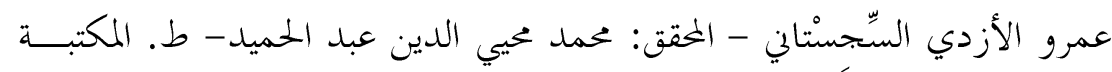

$$
\text { العصرية، صيدا - بيروت. }
$$

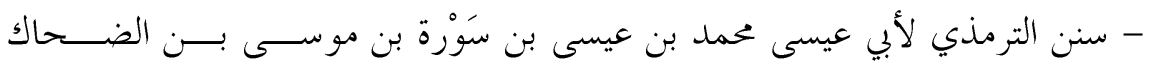

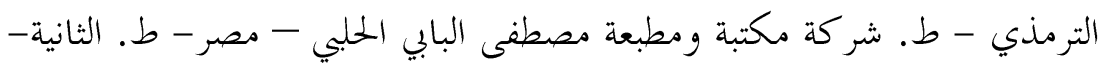

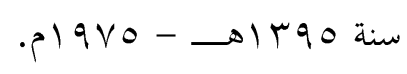

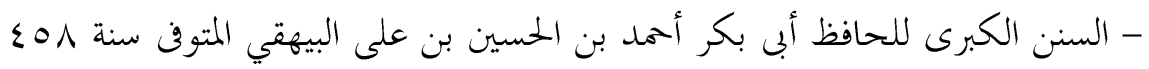

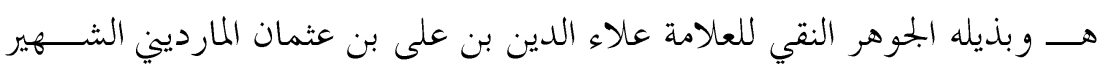

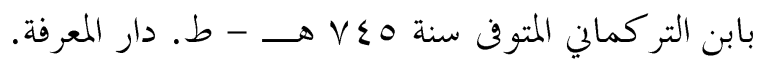

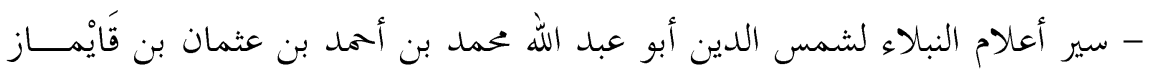

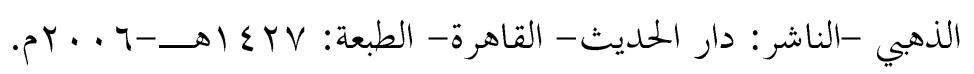

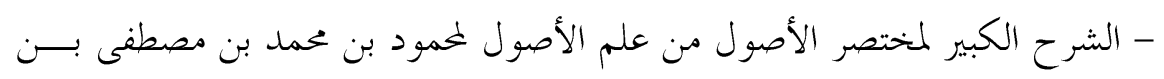

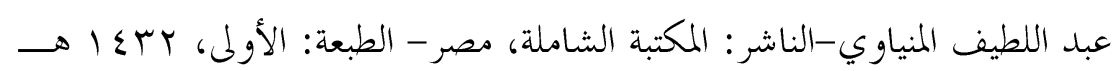

$$
\text { r. } 11-
$$

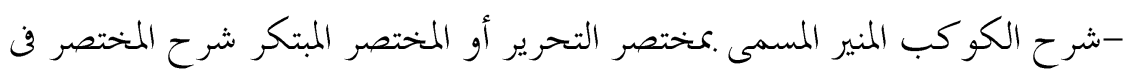

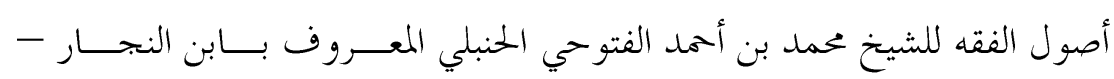

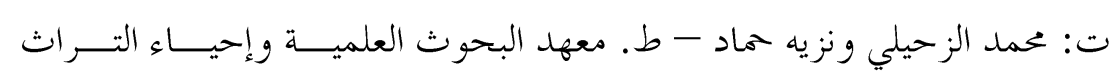

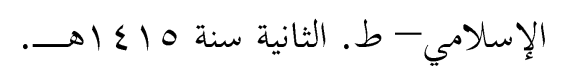

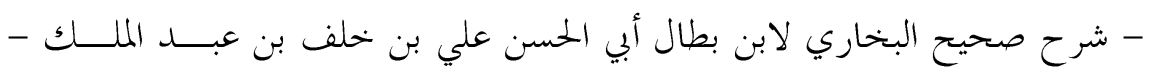

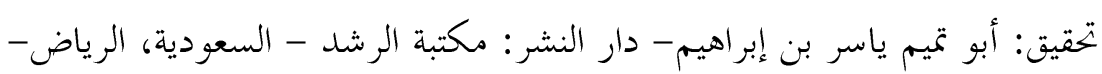

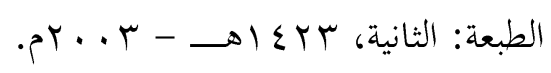

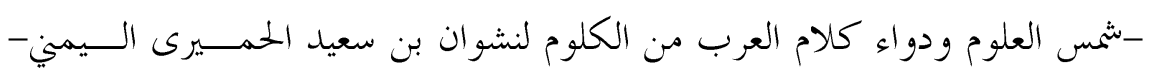

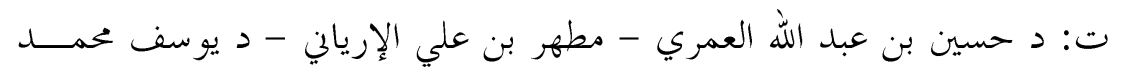

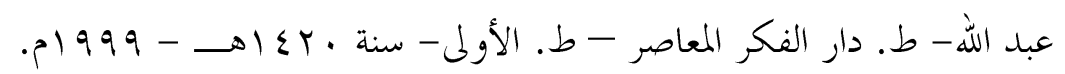




\section{الأسباب المعرفية للانحرافات الفكرية ومنهج السنة النبوية في معالجتها}

-الصحاح تاج اللغة وصحاح العربية لأبي نصر إسماعيل بن حماد الجوهري الفارابي -

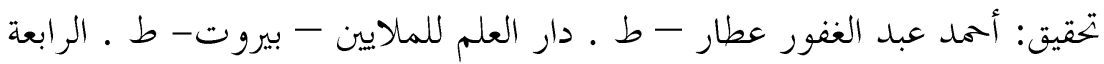

$$
\text { - } 191 \text { - }
$$

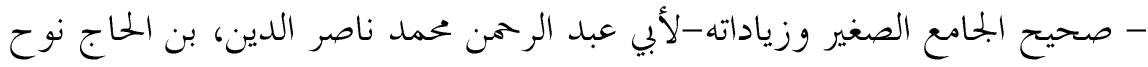

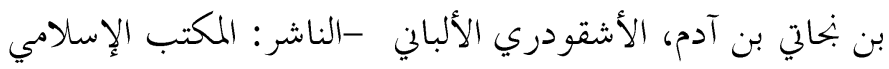

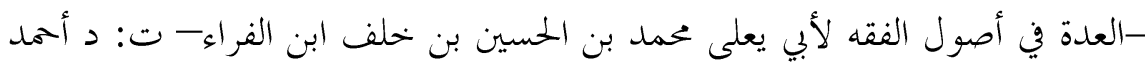

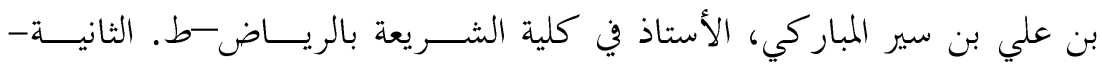

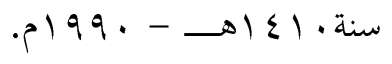

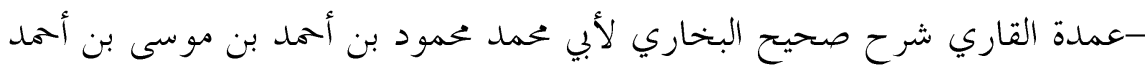

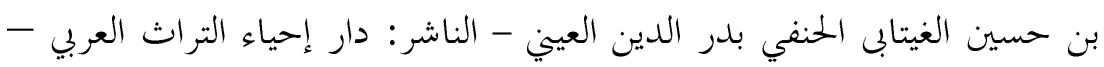

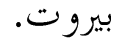

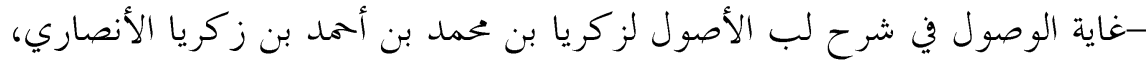

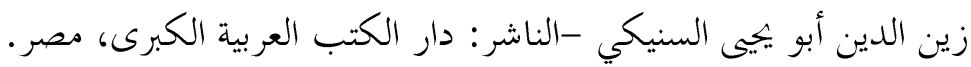

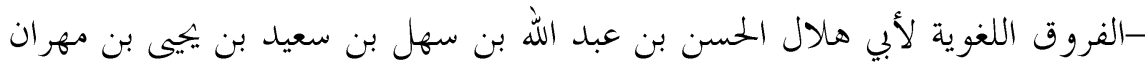

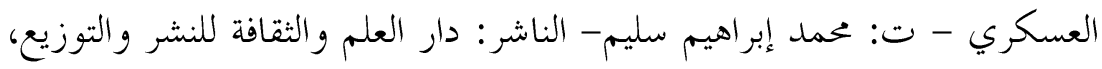

$$
\text { القاهرة - مصر. }
$$

- كشف المشكل من حديث الصحيحين-لجمال الدين أبو الفرج عبد الرحمن بن علي

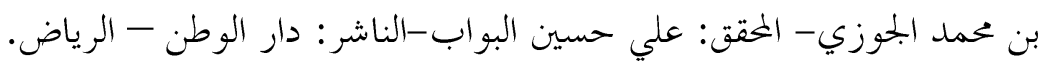

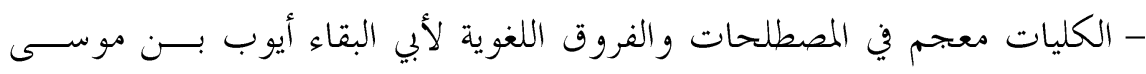

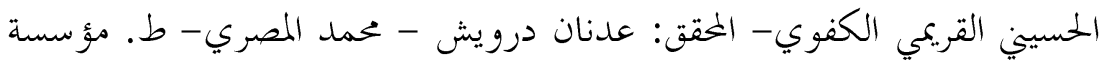

$$
\text { الرسالة. }
$$

- لسان العرب لجمال الدين أبي الفضل محمد بن مكرم بن على ابن منظور الأنصاري

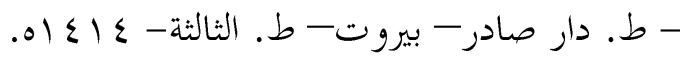




\section{مجلة كلية الدراسات الإسلامية والعربية للبنات بدمنهور العدد الخامس الجزء السادس •r.rم}

- بحموع الفتاوى لتقي الدين أبو العباس أحمد بن عبد الحليم بن تيمية الحرابي-المحقق:

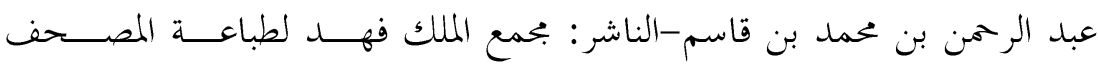

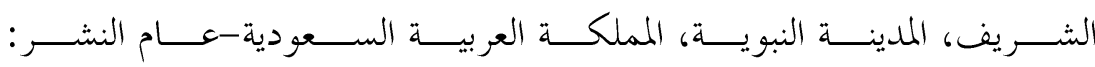

$$
\text { م) 1990/-ه1 (1) }
$$

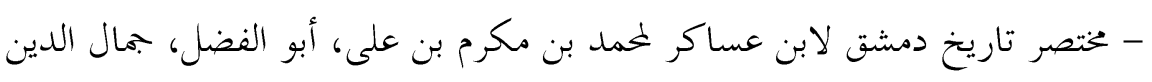

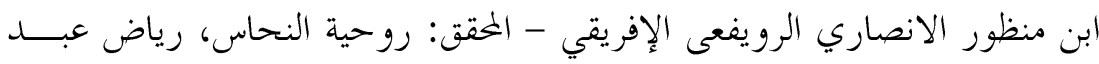

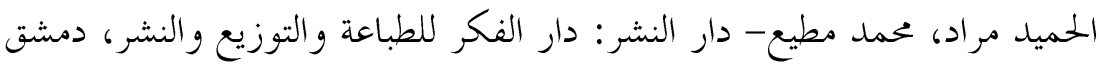

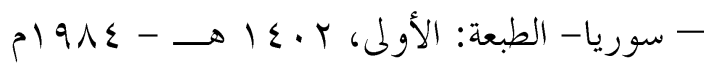

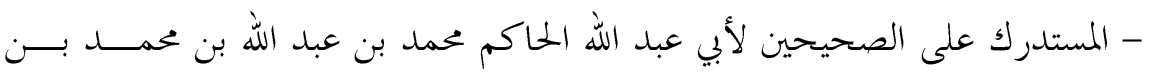

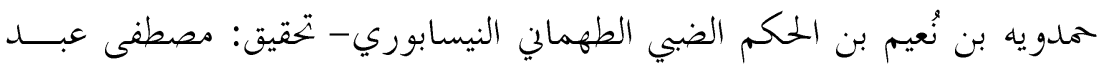

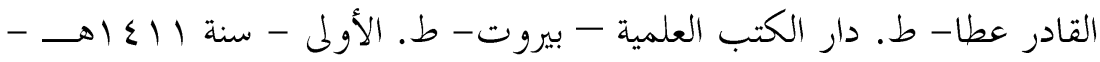

$$
.0199 \text {. }
$$

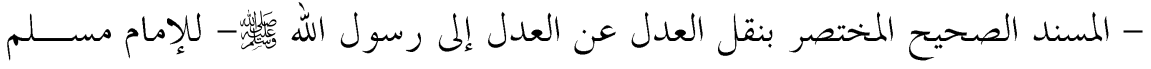

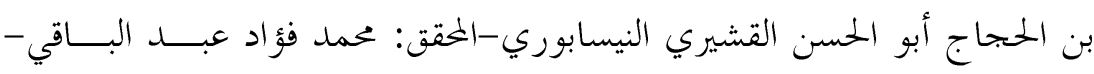

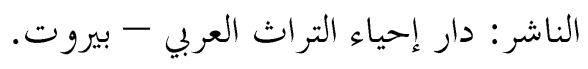

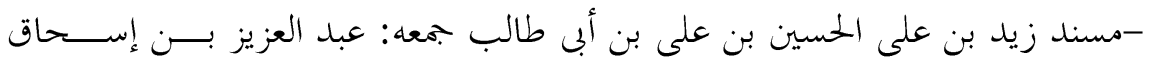

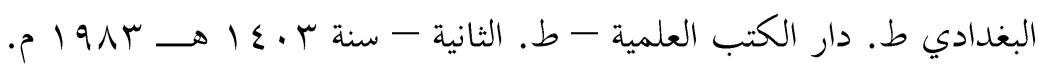

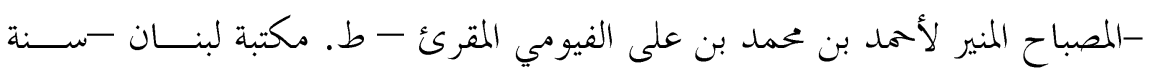

$$
\text { .p) } 91 \mathrm{~V}
$$

-معجم الفروق اللغوية لأبي هلال الحسن بن عبد الله بن سهل بن سعيد بن يهيى بن

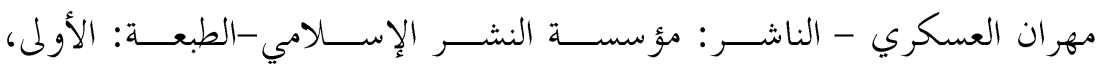

- معجم اللغة العربية المعاصرة- المؤلف: د أحمد يختار عبد الحميد عمر - الناشـــر:

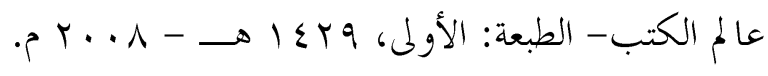




\section{الأسباب المعرفية للانحرافات الفكرية ومنهج السنة النبوية في معالجتها}

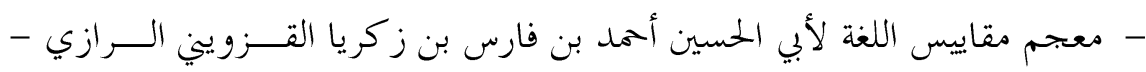

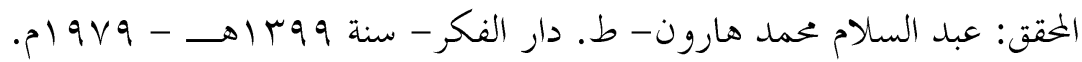

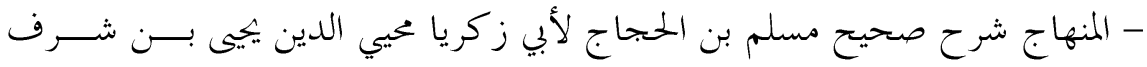

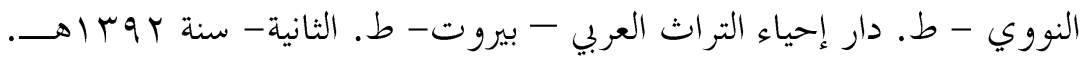

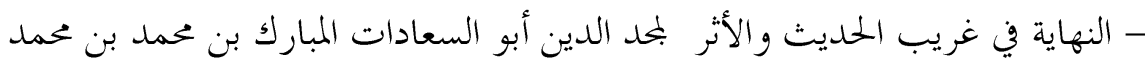

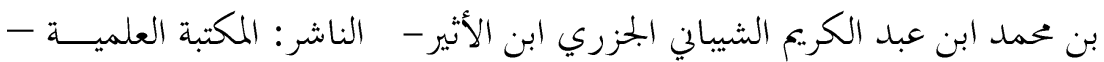

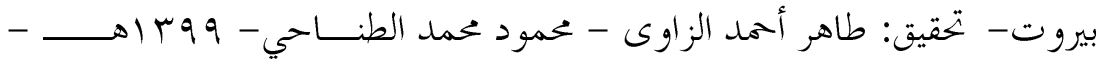
$.019 \vee 9$ - الوجيز في أصول الفقه الإسلامي للأستاذ الدكتور محمد مصطفى الزحيلـيـ- ط.

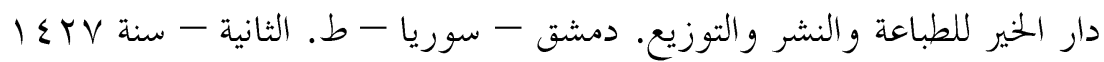
ه - و وائل التو اصل الاجتماعي وأثرها على الأمن الفكري من وجهة نظر طلبة المرحلة الثانوية ومعلمي العلوم الشرعية بمنطقة عسير - بحث منشور في بحلة كلية التربية

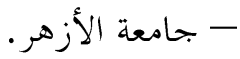


مجلة كلية الدراسات الإسلامية والعربية للبنات بدمنهور العدد الخامس الجزء السادس •r+rم

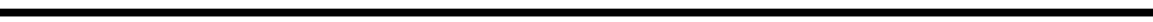

